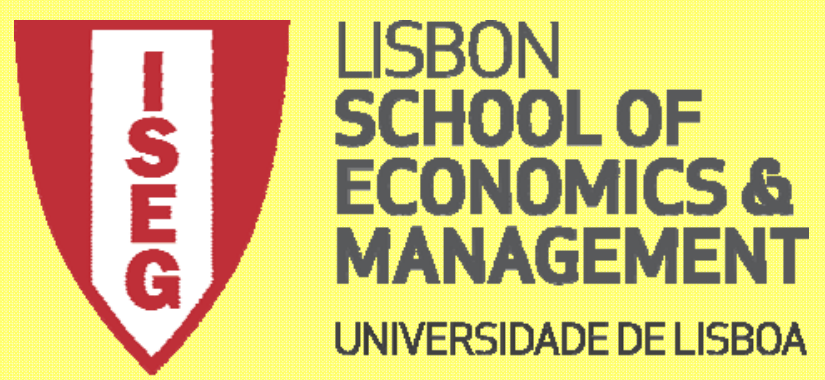

Department of Ec onomics

\author{
António Afonso, André Albuquerque \\ Sovereign Credit Rating Mismatches
}

WP022017/DE/UECE

WORKING PAPERS

ISSN 2183-1815

U

LISBOA

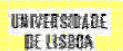




\title{
Sovereign Credit Rating Mismatches
}

\author{
António Afonso $\$$, André Albuquerque
}

2017

\begin{abstract}
We study the factors behind split ratings in sovereign credit ratings from different agencies, for the period 1980-2015. We employ random effects ordered and simple probit approaches to assess the explanatory power of different macroeconomic, government and financial variables. Our results show that structural balances and the existence of a default in the last ten years were the least significant variables whereas the level of net debt, budget balances, GDP per capita and the existence of a default in the last five years were found to be the most relevant variables explaining rating mismatches across agencies. For speculative-grade ratings, we also find that a default in the last two or five years decreases the rating difference between S\&P and Fitch. For the positive rating difference between S\&P and Moody's for investment-grade ratings, an increase in external debt leads to a smaller rating gap between the two agencies
\end{abstract}

JEL: C23; C25; E44; F34; G15; H63

Keywords: sovereign ratings; split ratings; panel data; random effects ordered probit

\footnotetext{
\$ ISEG/ULisboa-Universidade de Lisboa, Department of Economics; UECE - Research Unit on Complexity and Economics, R. Miguel Lupi 20, 1249-078 Lisbon, Portugal, email: aafonso@iseg.utl.pt. UECE is supported by the Fundacão para a Ciência e a Tecnologia (Portuguese Foundation for Science and Technology) through the PEstOE/EGE/UI0436/2011 project. Email: aafonso@iseg.utl.pt.

\# ISEG/ULisbon - University of Lisbon, R. Miguel Lupi 20, 1249-078 Lisbon, Portugal. Email: andre.malbuq@gmail.com.
} 


\section{Introduction}

In the current global financial system, credit rating agencies play a crucial role in reducing information asymmetries in the financial markets and more recently also provide a fundamental input to the financial institutions risk assessment required by regulators, since capital requirements are calculated by applying to the institution financial assets a weighting factor depending on the associated credit rating. Sovereign credit ratings summarise in an ordinal qualitative scale a complex and thorough analysis of the ability a country has to service its debt. Since institutional investors nowadays are only allowed to acquire financial assets above a certain rating, countries willing to issue debt are in practice obliged to pay for a credit rating.

With the globalization of financial markets and the proliferation of credit ratings, rating agencies assigning different credit ratings to the same country became more frequent. Our contribution is twofold: first, we set up the possible pairs of rating mismatches across the three main rating agencies for 105 countries, highlighting persistent split ratings; second, we analysed the rating differences between S\&P, Moody's and Fitch in the light of a random-effects probit framework and using as explanatory variables a set of macroeconomic variables found in the literature as important determinants of sovereign ratings.

Our ordered probit results found, for every dataset used, that the structural balance did not contribute to any rating difference here considered. Only the simple probit regressions found that structural balances explain some of the split ratings. The structural balance and the default in the last ten years were the least significant across all our regressions, whereas the level of net debt, budget balances, per capita GDP and a default in the last five years contribute in more than $20 \%$ of the regressions to the rating differences. In addition, for speculative-grade ratings, we find that a default in the last two or five years decreases the rating difference between $S \& P$ and Fitch. For the positive rating difference between S\&P and Moody's for investment-grade ratings, an increase in external debt leads to a smaller rating gap between the two agencies

The remainder of the paper is organized as follows: section two provides the literature review; section three explains the methodology; section four discusses the results of the analysis; and section five is a conclusion. 


\section{Literature}

In spite of being a century old, ${ }^{1}$ credit ratings only began to play a role in US financial market regulation in 1931, and over time the reliance by regulators on the information conveyed by ratings increased. According to Levich et al. (2012), this increasing usage led, in 1975, to the establishment of guidelines by the US Securities and Exchange Commission for designating National Recognized Statistical Rating Organizations (NRSROs). Given the growing globalization of banking and financial markets since the 1970s, the Bank for International Settlements established a set of risk-based capital adequacy levels, which in 1999 were revised to explicitly consider credit ratings in determining a bank's risk capital.

According to Bhatia (2002), the first sovereign credit ratings were issued by Moody's "just before World War I". ${ }^{2}$ Before the Great Depression, the predecessor of S\&P rated bonds from 21 national governments in Europe, South America, North America and Asia. Most sovereign ratings were then suspended during World War II and only after the war, S\&P and Moody's began again to rate bonds issued by major industrialized countries. The withdrawal in 1974 of a tax applied to foreign borrowers in 1963 in the US which had driven bond market activity out of the US, marked the beginning of the modern sovereign credit ratings era.

Amstad and Packer (2015) define sovereign ratings as "opinions about the creditworthiness of sovereign borrowers that indicate the relative likelihood of default on their outstanding debt obligations". These ratings, like the ratings about other types of credit, try to assess both the ability and willingness of the borrower to pay. To accomplish this, qualitative factors, like institutional strength and the rule of law, and quantitative factors, like measures of fiscal and economic strength, the monetary regime, foreign exchange reserves, are analysed to rate a sovereign issuer. Kiff et al. (2012) state that ratings are not only about credit risk but also convey information about credit stability (changes in credit risk), and the assessments represented by ratings are medium-term outlooks that should not change due to the impact of cyclical components. Rating volatility should be minimized by rating agencies by assessing through the cycle: a rating should be changed only to reflect a shift in fundamental factors (and consequently a change in basic creditworthiness), and not as a response to a recession or a global liquidity shortage, for example. Kiff et al. (2012) description of this approach is particularly accurate: "vulnerability to cycles affects the rating decision, whereas the current position in the cycle does not".

\footnotetext{
${ }^{1}$ John Moody founded the first rating agency in 1909, in the United States, and their first ratings were entirely for the bonded debts of US railroads (see Sylla, 2002).

${ }^{2}$ In our rating dataset the oldest sovereign rating, a 'AAA' rating, was given by S\&P to Finland in April 1972.
} 
Bhatia (2002) affirms that the widespread use by investors of the credit ratings attributed by Standard \& Poor's (S\&P), Moody's Investors Service (Moody's) and Fitch Ratings (Fitch) reflects their utility for the market. This usefulness results from the simplicity and comparability of the rating systems used by those rating agencies, condensing detailed analysis into brief indicators, and from the "perceived analytical strength and independence of the agencies themselves". ${ }^{3}$ Issuers pay for the ratings, expecting to attract more investors, or simply to obtain an assessment of their risk, often asking more than one agency for a rating at the same time. On the other hand, investors incorporate ratings in their decision process (pricing calculations, decisions to buy, sell or hold), turning credit ratings into an integral part of today's capital markets.

A sovereign credit rating normally serves as the "ceiling" of the ratings within its territory, since the sovereign bond yields are considered riskless and therefore used as a benchmark against which returns on domestic investments are compared. In parallel, each sovereign creditworthiness is compared with the most trustworthy issuers (rated with an 'AAA' rating), and among those is the German government, whose bonds are regarded as one of the global risk-free benchmarks. Given the increasing connectedness of the capital markets, the growing issuance of bonded debt and the regulatory role of sovereign ratings on investors risk management, changes in sovereign ratings can have profound implications.

Both the Asian crisis in 1997 and the global financial crisis of 2007-08 highlighted flaws in the rating systems. In the first case, a rating approach based only on macroeconomic fundamentals was the culprit, revealing the importance of contingent liabilities and the international liquidity position of the issuers (Bhatia (2002)). In the latter case, and according to Brunnermeier (2009), one of the deciding factors contributing to the latest financial crisis was the collaboration between banks and rating agencies to ensure their structured debt products (often called collateralized debt obligations (CDO)), had always a tranche reaching the 'AAA' rating, even if the underlying default risk was not equivalent to the default risk associated with a 'AAA' bond rating. Fund managers were attracted to buying these structured products offering seemingly high expected returns with an acceptable level of risk, and when the quality of the securitized assets deteriorated (signalled by a spike in the default rate of the so-called subprime mortgages), every holder inevitably faced losses and eventually had to write-down a significant part of their mortgage-related securities.

\footnotetext{
${ }^{3}$ Table II compares the rating scales of the three main credit rating agencies.
} 
In the wake of the global financial crisis and the European sovereign debt crisis, Amstad and Packer (2015) highlight the changes in the sovereign risk methodologies used by the major rating agencies. These rating methodologies explain which factors drive the evaluation of the likelihood of default. A common principle to these revisions is that agencies tried to adopt assessment systems more reliant on quantitative inputs, to make ratings more transparent and replicable ${ }^{4}$.

Moody's rating methodology will now be analysed, to illustrate how the rating methodologies are now more reliant on quantitative inputs. Moody's Investors Service (2015) explains how it bases its sovereign credit risk assessment on the "interplay" of four key factors: economic strength, institutional strength, fiscal strength and susceptibility to event risk. The following figure show how Moody's broad factors interact to ultimately produce a sovereign credit rating.

Figure 1 - Key factors affecting Moody's credit risk assessment.

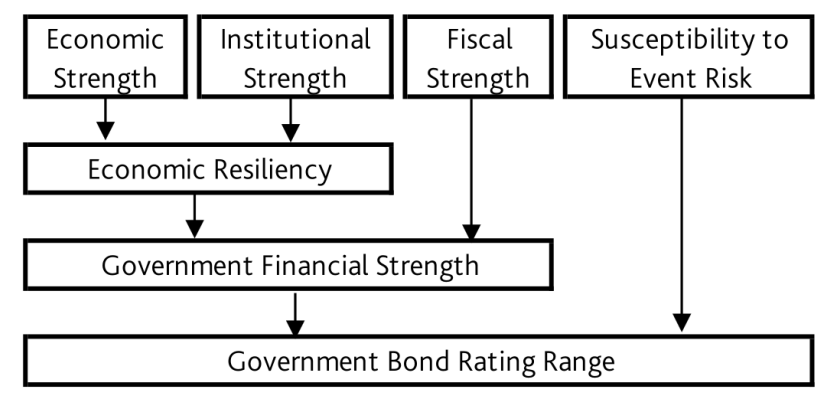

Source: Moody's Investors Service (2015).

These broad rating factors are subdivided into sub-factors, each with a different weight towards the broad factor.

The transparency achieved by the revision of the Moody's risk assessment methodology is illustrated by Cantor (2012), who showed that using the indicators underlying each factor and their weights as a scorecard, one could predict $70 \%$ of Moody's bond ratings within two notches and explain $67 \%$ of the variation in bond ratings.

Al-Sakka and ap Gwilym (2010) associate the growing importance of credit rating agencies to the increasing number of issuers and debt products, and globalization, but also to the requirements applied to institutional investors, banks and financial institutions: the first ones are only allowed to trade debt securities rated by NRSROs, whereas the latter, stemming from

\footnotetext{
${ }^{4}$ Amstad and Packer (2015) find that ratings can be largely explained by a relatively small set of fewer than 10 variables, in line with the results of previous studies.
} 
the Basel II Accord, are obliged to use external credit ratings to assess their credit risks and to determine capital adequacy requirements.

Table I provides further detail about how Moody's arranges sub-factors into each broad rating factor.

The transparency achieved by the revision of the Moody's risk assessment methodology is illustrated by Cantor (2012), who showed that using the indicators underlying each factor and their weights as a scorecard, one could predict $70 \%$ of Moody's bond ratings within two notches and explain $67 \%$ of the variation in bond ratings.

Al-Sakka and ap Gwilym (2010) associate the growing importance of credit rating agencies to the increasing number of issuers and debt products, and globalization, but also to the requirements applied to institutional investors, banks and financial institutions: the first ones are only allowed to trade debt securities rated by NRSROs, whereas the latter, stemming from the Basel II Accord, are obliged to use external credit ratings to assess their credit risks and to determine capital adequacy requirements.

Table I - Identification of Moody's key rating factors and corresponding sub-factors.

\begin{tabular}{l|l}
\hline Broad rating factors & $\begin{array}{l}\text { Rating sub-factor } \\
\text { Factor 1: Economic strength }\end{array}$ \\
& $\begin{array}{l}\text { Scale of the economy } \\
\text { National income }\end{array}$ \\
\hline Factor 2: Institutional strength & $\begin{array}{l}\text { Institutional framework and effectiveness } \\
\text { Policy credibility and effectiveness }\end{array}$ \\
\hline Factor 3: Fiscal strength & Debt burden \\
& Debt affordability \\
\hline Factor 4: Susceptibility to event risk & $\begin{array}{l}\text { Political risk } \\
\text { Government liquidity risk }\end{array}$ \\
& Banking sector risk \\
External vulnerability risk
\end{tabular}

Source: Moody's Investors Service (2015). Note: each sub-factor encompasses one or more indicator, like average real GDP growth and volatility, nominal GDP, GDP per capita, inflation level and volatility, etc.

The determinants of sovereign credit ratings are an object of study since the seminal work of Cantor and Packer (1996), a cross sectional OLS estimation which identified per capita income, GDP growth, inflation, external debt, level of economic development and default history as important determinants of sovereign ratings assigned by Moody's and S\&P. This methodology was also used by Afonso (2003), which also included a logistic and an exponential 
transformation of the ratings, in addition to the linear transformation already used. Mulder and Monfort (2000) and Eliasson (2002) generalized the OLS approach to panel data, both using a linear transformation of the ratings.

On the other hand, and to overcome the limitation of OLS regressions with a linear transformation of the ratings, Bissoondoyal-Bheenick (2005) used an ordered probit model for a period of five years and 95 countries. ${ }^{5}$

Afonso et al. (2008) analysed the determinants of sovereign ratings from the three main agencies by using a linear regression framework (random effects estimation, pooled OLS estimation and fixed effects estimation) versus an ordered probit response framework. ${ }^{6}$ In addition, Afonso et al. (2011) confirm that logistic and exponential transformations to ratings provide little improvement over the linear transformation, not finding evidence of the so-called "cliff effects" (when investors adjust their portfolio composition to select only investment grade securities). This work also highlights the difference between short- and long-term determinants, concluding that GDP per capita, GDP growth, government debt and budget balance have a short-term impact, whereas government effectiveness, external debt, foreign reserves and default history influence ratings in the long-run.

Starting with Cantor and Packer (1996) selection of macroeconomic variables, the work from different authors that followed progressively converged into a subset of determinants, present in every study here analysed: the level of GDP per capita, real GDP growth, external debt, the level of public debt and the government budget balance were found to predominantly explain the rating scale. In line with the results of previous studies, the recent work of Amstad and Packer (2015), used several explanatory variables as proxies for fiscal, economic and institutional strength, monetary regime, external position and default history and also concludes that a small set of factors can largely explain the rating scale.

\section{Methodology}

To understand which factors may explain split sovereign ratings and if some of those factors are considered more relevant by certain agencies, we propose to analyse the collected dataset using a random-effects probit regression framework.

\footnotetext{
${ }^{5}$ An OLS regression with a linear transformation of the ratings assumes a constant distance between adjacent rating notches. However, ratings represent a qualitative ordinal assessment of a sovereign credit risk, thus the distance between two adjacent ratings may not be the same

${ }^{6}$ Instead of assuming a rigid shape of the ratings scale, this model estimates the threshold values between rating notches, defining the shape of the ratings curve.
} 
The source of the information used to create the dependent variables were the rating changes for long-term sovereign foreign currency ratings obtained from Bloomberg for the three main credit rating agencies (Standard \& Poor's, Moody's, and Fitch Ratings). For each country and for each year, the last rating change of the year was selected as that country's year rating. Years without any rating change were filled by extending the rating of the previous year and rating withdrawals by the rating agencies were ignored, since the rating given before the withdrawal keeps its relevance for the markets.

The qualitative rating given by the rating agencies were then converted into a numerical scale, from 0 to 21 , where 21 corresponded to the 'AAA' from S\&P and Fitch/'Aaa' from Moody's and 0 corresponded to a (selective) default, using the correspondence in Table II.

Table II - A comparison between rating agencies qualitative scales.

\begin{tabular}{|c|c|c|c|}
\hline Rating number & $S \& P$ & Moody's & Fitch \\
\hline $\begin{array}{l}21 \text { (Highest credit } \\
\text { rating) }\end{array}$ & AAA & Aaа & AAA \\
\hline 20 & $\mathrm{AA}+$ & Aa1 & $\mathrm{AA}+$ \\
\hline 19 & AA & $\mathrm{Aa} 2$ & AA \\
\hline 18 & AA- & Aa3 & AA- \\
\hline 17 & $\mathrm{~A}+$ & A1 & $\mathrm{A}+$ \\
\hline 16 & A & $\mathrm{A} 2$ & A \\
\hline 15 & A- & A3 & A- \\
\hline 14 & $\mathrm{BBB}+$ & Baa1 & $\mathrm{BBB}+$ \\
\hline 13 & $\mathrm{BBB}$ & $\mathrm{Baa} 2$ & $\mathrm{BBB}$ \\
\hline 12 & BBB- & Baa3 & BBB- \\
\hline 11 & $\mathrm{BB}+$ & Ba1 & $\mathrm{BB}+$ \\
\hline 10 & $\mathrm{BB}$ & $\mathrm{Ba} 2$ & $\mathrm{BB}$ \\
\hline 9 & BB- & $\mathrm{Ba} 3$ & BB- \\
\hline 8 & $\mathrm{~B}+$ & B1 & $\mathrm{B}+$ \\
\hline 7 & B & B2 & B \\
\hline 6 & B- & B3 & B- \\
\hline 5 & $\mathrm{CCC}+$ & Caa1 & $\mathrm{CCC}+$ \\
\hline 4 & $\mathrm{CCC}$ & $\mathrm{Caa} 2$ & $\mathrm{CCC}$ \\
\hline 3 & CCC- & Caa4 & CCC- \\
\hline 2 & $\mathrm{CC}$ & $\mathrm{Ca}$ & $\mathrm{CC}$ \\
\hline 1 & $\mathrm{C}$ & $\mathrm{C}$ & $\mathrm{C}$ \\
\hline 0 & SD/D & & DDD/D \\
\hline
\end{tabular}

Note: According to S\&P Global Ratings (2016), Moody’s Investors Service (2016), Fitch Ratings (2014), we considered a numerical sovereign rating of 12 or above to be an investment-grade rating, whereas a rating below that value would be considered a speculative-grade rating. 
Our six dependent variables - Diff_UP ${ }_{i t}^{S F}$, Diff_DW ${ }_{i t}^{S F}$, Diff_UP ${ }_{i t}^{M F}$, Diff_DW ${ }_{i t}^{M F}$, $D i f f \_U P_{i t}{ }^{S M}$ and Diff_D $D W_{i t}{ }^{S M}$ - represent the difference in ratings between the credit rating agencies considered in this work. Their definition follows:

- Diff_UP $\boldsymbol{P}_{i t} \boldsymbol{S}$. It represents the difference between the numeric ratings given by S\&P and Fitch, when S\&P rating was higher or equal than Fitch's rating for the pair (country $i$, year $t$ );

- Diff_D $\boldsymbol{D} \boldsymbol{W}_{i t} \boldsymbol{S F}$. It represents the difference between the numeric ratings given by S\&P and Fitch, when S\&P rating was lower or equal than Fitch's rating for the pair (country $i$, year $t$ );

- Diff_UP ${ }_{i t}{ }^{M F}$. It represents the difference between the numeric ratings given by Moody's and Fitch, when Moody's rating was higher or equal than Fitch's rating for the pair (country $i$, year $t$ );

- $\quad$ Diff_ $D W_{i t}{ }^{M F}$. It represents the difference between the numeric ratings given by Moody's and Fitch, when Moody's rating was lower or equal than Fitch's rating for the pair (country $i$, year $t$ );

- Diff_UP ${ }_{i t}{ }^{S M}$. It represents the difference between the numeric ratings given by S\&P and Moody's, when S\&P rating was higher or equal than Moody's rating for the pair (country $i$, year $t$ );

- Diff_ $\boldsymbol{D} \boldsymbol{W}_{i t}{ }^{S M}$. It represents the difference between the numeric ratings given by S\&P and Moody's, when S\&P rating was lower or equal than Moody's rating for the pair (country $i$, year $t$ )

As an example, let $R_{i t}{ }^{X}$ represent the rating from credit rating agency $X$ for the country $i$ in year $t$ and consider the dependent variable Diff_UP ${ }_{i t}^{S M}$, representing the difference between S\&P and Moody's ratings: Diff_UP ${ }_{i t}{ }^{S M}=R_{i t}{ }^{S}-R_{i t}{ }^{M}$, when $R_{i t}{ }^{S}>=R_{i t}{ }^{M}$. If Diff_UP $P_{i t}{ }^{S M}>0$, then $\mathrm{S} \& \mathrm{P}$ considers country $i$, in time $t$, more capable of fulfilling its debt obligations than what Moody's finds about the capacity of country $i$ to pay its debt.

This work reports on the results produced by an ordered and a simple probit models and as a result, the values of the dependent variables were transformed accordingly: the target variables of the ordered probit model may assume the values 0,1 or 2 (as defined by equation (3)), whereas the target variables of the simple probit model may only assume the values 0 or 1 (see equation (5)). 


\subsection{Explanatory variables}

The explanatory variables used in this study were selected according to the existing literature on the determinants of sovereign ratings, where we find previous papers trying to estimate the predictors of sovereign debt rating notations using both linear (see Cantor and Packer (1996), Afonso (2003), Afonso et al. (2011)) and ordered response models (see Afonso et al. (2008), Afonso et al. (2011)). According to these papers, the predictors which better explain the rating scale are: the level of GDP per capita, real GDP growth, external debt, government debt and the government budget balance.

In addition to the mentioned predictors ${ }^{7}$, this work also considered as explanatory variables the government structural balance, inflation and the default history of a country. Here follows the list of explanatory variables used in this work ( 0 describes in more detail each one of these, along with its corresponding source and how each variable was created):

- Budget balance. Overall difference between government revenues and spending. Successive budget deficits may signal problems with the implemented policies;

- Structural balance. By decomposing the budget balance into its cyclical and noncyclical components, one can better understand the cyclical influences on the budget balance. Changes in the non-cyclical, or structural, component, may be indicative of discretionary policy adjustments;

- Gross debt. Summation of all liabilities that will require payments of interest and/or principal by the government;

- Net debt. Net debt is calculated as gross debt minus the financial assets a government holds;

- GDP growth rate. Annual growth rate of the Gross Domestic Product. A higher value strengthens the government ability to pay its debt;

- GDP per capita. Also called per capita income, measures the average income per person in a country;

- Inflation. Annual increase of average consumer prices, over a period of time. It helps governments by reducing the real stock of outstanding debt in domestic currency, but a consistent high value is associated with macroeconomic imbalances;

\footnotetext{
${ }^{7}$ Regarding government debt, we have analysed both gross and net government debt separately.
} 
- External debt. Also called foreign debt, represents the total debt a country (its government, corporations and citizens) owes to foreign creditors. It does not include contingent liabilities;

- Default-in-the-last-year/2-years/5-years/10-years. These variables represent a default in the last year, two, five or ten years. The definition of default by Beers and Mavalwalla (2016) here used is consistent with the literature on sovereign defaults and considers that "a default has occurred when debt service is not paid on the due date, payments are not made within the time frame specified under a guarantee or, absent an outright payment default, creditors face material economic losses on the sovereign debt they hold".

\subsection{Probit regression framework}

In this work we used both a random effects ordered probit and simple probit panel model, similar to what Afonso et al. (2011) used to identify the determinants of sovereign debt credit ratings and what Al-Sakka and ap Gwilym (2010) used to analyse the impact of split ratings on sovereign rating changes. According to Afonso et al. (2011), the ordered and simple probit random-effects estimations consider the existence of an additional cross-country error term and therefore yield better results using panel data when compared with linear regression methods or fixed-effects probit estimations.

Our approach considers the discrete, ordinal nature of rating differences between credit rating agencies. The negative and positive rating differences for each pair of agencies was analysed separately due to expected disparate behaviour, comparable to what Al-Sakka and ap Gwilym (2010) expected with rating migrations.

Consider our probit regression setting, when we are regressing Diff_UP ${ }_{i t}{ }^{S M}$ as the dependent variable (in this case, all observations have the rating from $\mathrm{S} \& \mathrm{P}$ higher or equal than the rating from Moody's). If the resulting coefficient of an explanatory variable, say, real GDP growth, is positive and significant, we conclude that an increase in real GDP growth will contribute to a bigger difference between S\&P and Moody's ratings ${ }^{8}$. In a similar way, if the coefficient of the level of public debt is negative, we may conclude that an increase in the level of public debt, will contribute to a smaller difference between the ratings given by S\&P and Moody's 9 .

\footnotetext{
${ }^{8}$ This could be interpreted as an increase in real GDP growth contributing to a higher S\&P rating or a lower Moody's rating.

${ }^{9}$ And in this case this could be interpreted as an increase in the level of public debt contributing to a lower S\&P rating or a higher Moody's rating.
} 
Our probit specification is defined as follows, and the value of our $y_{i t}$ dependent variable depends on whether we are considering the ordered probit or the simple probit approach:

$$
\begin{aligned}
& y_{i t}=\beta_{1} \text { GovDebtProxy }_{i t}+\beta_{2} N G D P_{-} R P C H_{i t}+\beta_{3} N G D P D P C_{i t} \\
&+\beta_{4} \text { PCPIPCH }_{i t}+\beta_{5} \text { ExtDebtPercGNI }_{i t}+\gamma D e f a u l t Z_{i t} \\
&+\varepsilon_{i t} ; \varepsilon_{i t} \sim N(0,1) \\
& i=1, \ldots C(\text { no. of countries }), t=1, \ldots Y(\text { no. of years })
\end{aligned}
$$

where $y_{i t}$ is an ordinal variable equal to either Diff_UP ${ }_{i t}{ }^{A B}$ or Diff_D $W_{i t}{ }^{A B}$.

On our ordered probit model, Diff_UP ${ }_{i t}{ }^{A B}\left(D_{i f f} D W_{i t}{ }^{A B}\right)=1$ or 2 if the rating from agency $A$ is higher (lower) than the rating from agency $B$ by one or more-than-one-notch, respectively, for sovereign $i$ in year $t$, and 0 otherwise.

On our simple probit model, Diff_UP ${ }_{i t}{ }^{A B}\left(\operatorname{Diff}_{-} D W_{i t}{ }^{A B}\right)=1$ if the rating from agency $A$ is higher (lower) than the rating from agency $B$ by one or more notches, for sovereign $i$ in year $t$, and 0 otherwise.

GovDebtProxy $_{i t}$ may assume the variation value of the budget balance, gross debt, net debt or structural balance of country $i$ in year $t$, depending on the chosen specification ${ }^{10}$.

$N G D P \_R P C H_{i t}$ - growth rate of GDP for country $i$ in year $t$.

$N G D P D P C_{i t}$ - GDP per capita variation for country $i$ in year $t$.

PCPIPCH $H_{i t}$ - IPCH percentage change (inflation) for country $i$ in year $t$.

ExtDebtPercGNI $I_{i t}$ - external debt variation for country $i$ in year $t$.

Default $Z_{i t}$ - dummy variable taking the value of 1 if the country $i$ in year $t$ had defaulted in the last $Z$ years, and 0 otherwise.

In the scope of the ordered probit framework, our six dependent variables were defined as to only have values of 1, 2 or 0 , representing a rating gap of 1-notch, 2-or-more-notches or the inexistence of a rating gap, respectively. Equations 3 and (3 represent how the target variables were created:

$$
\operatorname{Diff}_{U P_{i t}^{\alpha \beta}}=\left\{\begin{array}{c}
1, \text { if }\left|R_{i t}^{\alpha}-R_{i t}^{\beta}\right|=1 \\
2, \text { if }\left|R_{i t}^{\alpha}-R_{i t}^{\beta}\right| \geq 2, \quad \text { when } R_{i t}^{\alpha} \geq R_{i t}^{\beta} \\
0, \text { otherwise }
\end{array}\right.
$$

\footnotetext{
${ }^{10}$ All variables are defined in Table A1.
} 


$$
\operatorname{Diff}_{D W_{i t}^{\alpha \beta}}=\left\{\begin{array}{c}
1, \text { if }\left|R_{i t}^{\alpha}-R_{i t}^{\beta}\right|=1 \\
2, \text { if }\left|R_{i t}^{\alpha}-R_{i t}^{\beta}\right| \geq 2, \\
0, \text { otherwise }
\end{array} \quad \text { when } R_{i t}^{\alpha} \leq R_{i t}^{\beta}\right.
$$

where $\alpha$ and $\beta \in\{S F, M F, S M\}$.

A simple probit regression was also run afterwards, and so the dependent variables were defined accordingly, by only assuming values of 0 or 1 , as one may see in the following equations:

$$
\begin{aligned}
& \text { Diff }_{U P_{i t}^{\alpha \beta}}=\left\{\begin{array}{c}
1, \text { if }\left|R_{i t}^{\alpha}-R_{i t}^{\beta}\right| \geq 1, \\
0, \text { otherwise }
\end{array}, \quad \text { when } R_{i t}^{\alpha} \geq R_{i t}^{\beta}\right. \\
& \text { Diff }_{D W_{i t}^{\alpha \beta}}=\left\{\begin{array}{c}
1, \text { if }\left|R_{i t}^{\alpha}-R_{i t}^{\beta}\right| \geq 1, \\
0, \text { otherwise }
\end{array} \quad \text { when } R_{i t}^{\alpha} \leq R_{i t}^{\beta}\right.
\end{aligned}
$$

where $\alpha$ and $\beta \in\{S F, M F, S M\}$.

This leads to, in the context of the simple probit regression, our dependent variables having a value of 1 if there is a rating difference of 1-notch or higher and a value of 0 if the ratings from the considered pair of agencies are equivalent in our numerical rating scale.

Independently of the ordered or simple probit setup, when an observation has equivalent ratings from the considered rating agencies, the value of both Diff_UP ${ }_{i t}^{\alpha \beta}$ and Diff_D $D W_{i t}{ }^{\alpha \beta}$ target variables is zero. Therefore, for each agency pair considered, both target variables use the same observations with no rating difference. ${ }^{11}$

Four different specifications of predicting variables were considered to overcome the correlation between some of the variables. Within each specification, the four different default dummies were combined. The composition of each specification can be seen on following table.

\section{Empirical analysis}

\subsection{Data}

With regards to the dependent variables, all the sovereign rating changes ${ }^{12}$ were downloaded from Bloomberg and converted into a numerical scale using Table II. Afterwards, we created six dependent variables (described in section 0), two variables for each rating agency

\footnotetext{
${ }^{11}$ An observation with $R_{i t}^{\alpha}=R_{i t}^{\beta}$ will make Diff_UP ${ }_{i t}^{\alpha \beta}=D i f f \_D W_{i t}{ }^{\alpha \beta}=0$, so it has to be considered on the regressions of both target variables.

${ }^{12} \mathrm{We}$ used the sovereign issuer ratings for foreign currency denominated debt.
} 
pair, with the value of each variable reflecting the numerical rating difference between the ratings given by those specific agencies (comparable to what Livingston et al. (2008) did with the split rated issues).

Figure 2 - Total number of countries rated by at least two credit rating agencies, and number of countries rated by each pair of the rating agencies considered in this work.

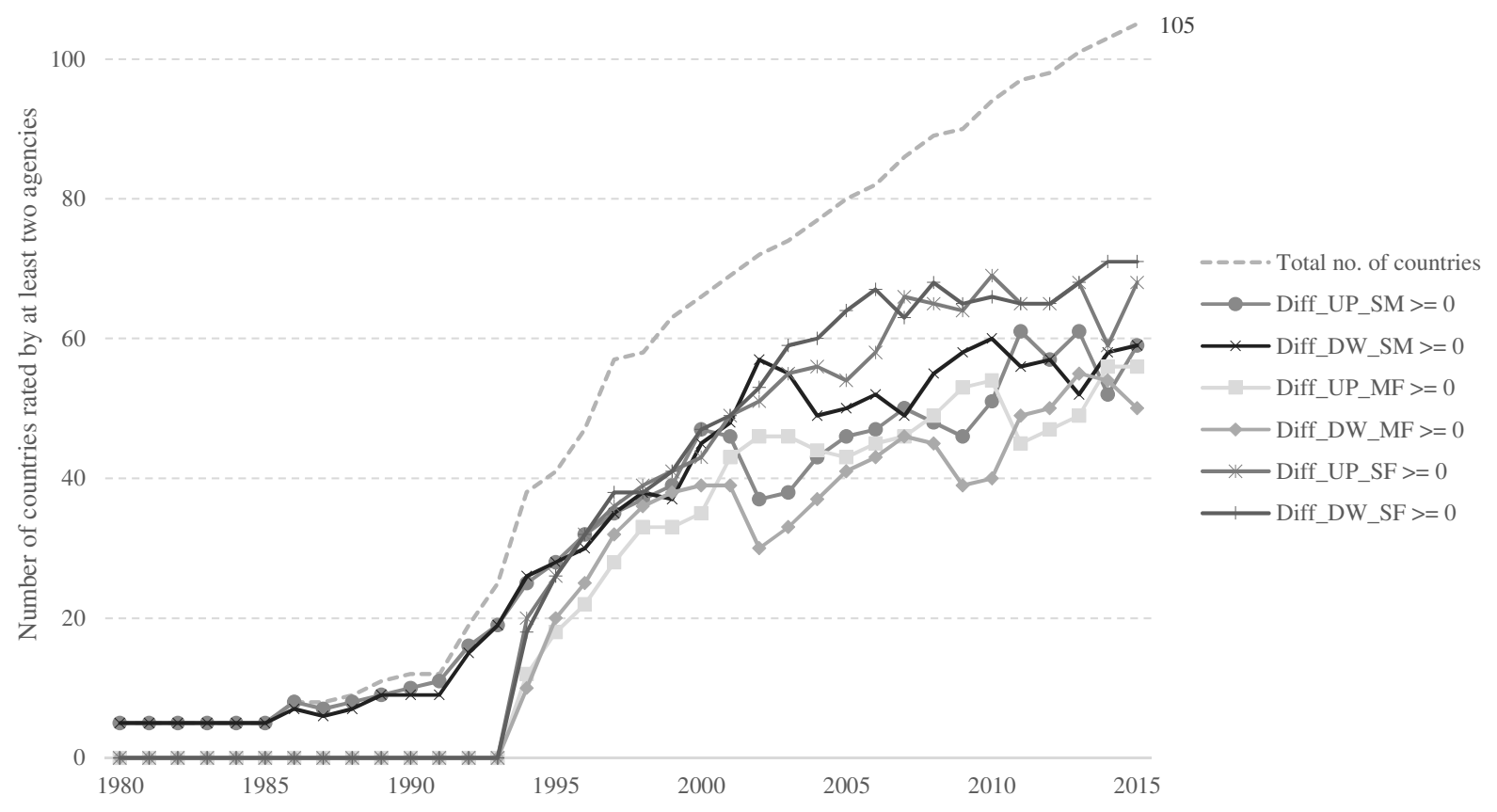

Source: rating agencies and own calculations.

The initial objective of this work was to study rating differences from 1970 onwards. However, and due to the inexistence of both macroeconomic values for many countries on those early years and ratings from at least two of the three selected agencies, our observations happened to comprehend only the period between 1980 and 2015. As Figure 2 illustrates, we only have observations with a rating from Fitch from 1994 onwards. From 1990 and until 2000, we observe a bigger increase in the number or countries rated by at least two agencies, whereas from 2000 onwards the pace of this increase slowed, ending with 105 countries in our dataset with ratings from at least two of the main rating agencies.

The distribution of the sovereign ratings on our dataset (seen in Figure 3) show that S\&P is the agency which assigns more countries a rating of 'AA-' or above, and that the great majority of our observations are equal or above 'B-'. A higher degree of agreement on the top of the rating scale may explain the number of observations which had a rating of 'AAA' from all three agencies. 
Figure 3 Distribution of the sovereign ratings composing our dataset. The time periods are 1980 to 2015 for S\&P and Moody's and 1994 to 2015 for Fitch.

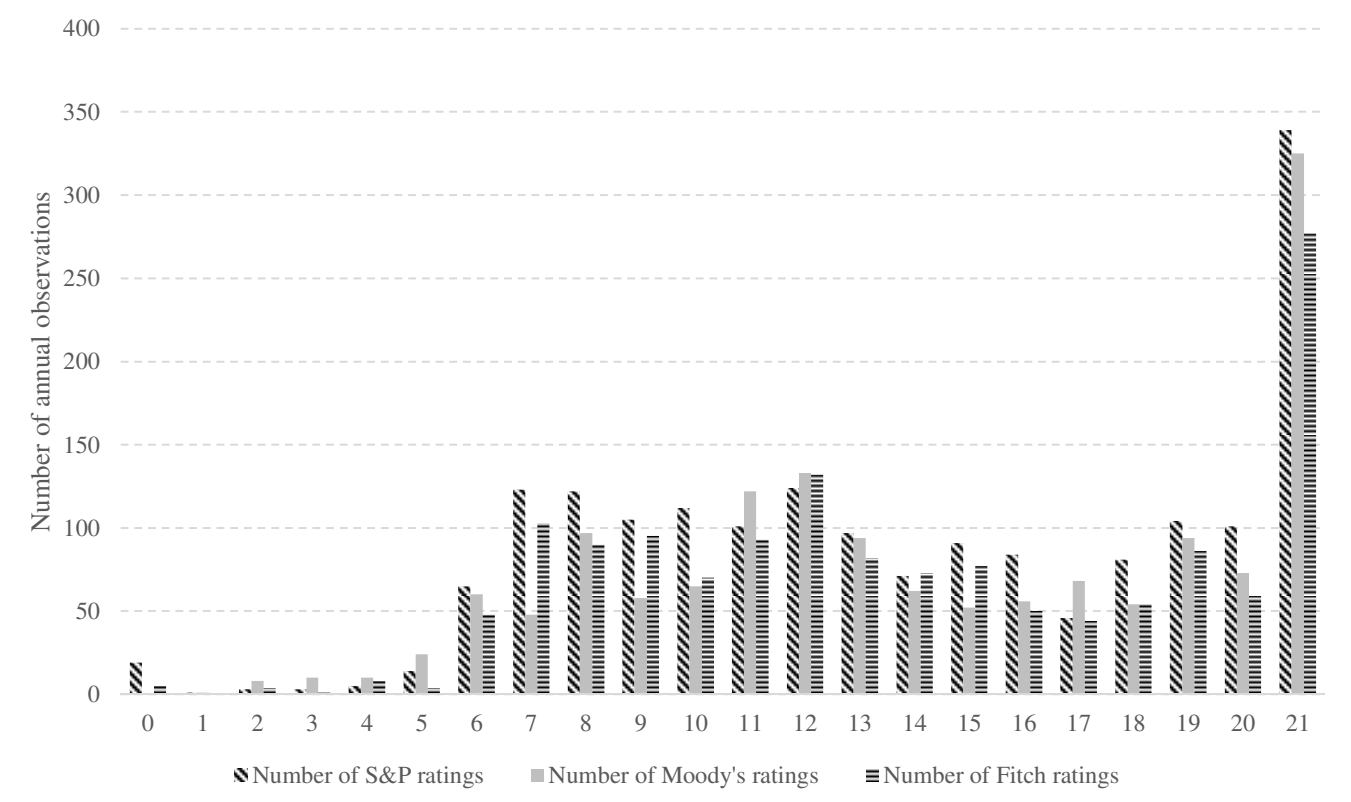

Source: rating agencies and own calculations.

Our independent variables were obtained from datasets from the IMF (World Economic Outlook), World Bank (World Development Indicators), Bank of Canada (Database of Sovereign Defaults) and from the Quarterly External Debt Statistics dataset developed in collaboration between the World Bank and the IMF. Details on how those variables were created can be found in the Appendix.

\subsection{Ordered probit panel results}

\subsubsection{Full sample}

We started by running the ordered probit regression with the full dataset. This dataset was composed by more than 850 observations for each dependent variable, comprised a period of at least 22 years (36 years only for the rating agency pair S\&P and Moody's) and 69 or more countries. More than $65 \%$ of our observations for each of our target variables had no rating difference, whereas a rating difference of 1-notch was found at least in $19 \%$ of the observations. A rating difference of two or more notches can only be found $3.5 \%^{13}$ of the times when analysing comparable ratings from S\&P and Fitch; on the other hand, $9 \%{ }^{14}$ of the observations

\footnotetext{
${ }^{13}$ This value was obtained by calculating the average of the percentages of a rating difference of two or more notches between S\&P and Fitch, when the first gave a higher rating than the latter $\left(\right.$ Diff_$\left._{-} U P_{i t}{ }^{S F}\right)$ and when the first gave a lower rating than the latter $\left(\right.$ Diff_D $\left.D W_{i t}^{S F}\right)$.

${ }^{14}$ This value was obtained by calculating the average of the percentages of a rating difference of two or more notches between S\&P and Moody's, when the first gave a higher rating than the latter $\left(\operatorname{Diff}_{-} U P_{i t}{ }^{S M}\right)$ and when the first gave a lower rating than the latter $\left(D_{i f f} D W_{i t}^{S M}\right)$.
} 
about the rating differences between S\&P and Moody's have a 2-notch rating difference. This shows how S\&P and Moody's disagree more when compared with the other rating agency pairs. Table III summarizes the full dataset.

Running the ordered probit regression for the full dataset, when the ratings from S\&P are higher or equal to Fitch own ratings (Diff_UP ${ }_{i t}^{S F}$ dependent variable), we get significant values for both budget balance and net debt variables. When budget balance increases, we expect the rating difference to decrease. For the net debt predicting variable the opposite occurs: when its value increases, the rating difference increases as well.

With regard to the Diff_ $D W_{i t}^{S F}$ dependent variable (ratings from S\&P being lower or equal to Fitch ratings), GDP per capita, external debt and the dummy default-in-the-last-5-years variables have statistically significant coefficients on all specifications. One can then conclude that if GDP per capita or external debt decrease, the rating difference between those two rating agencies increases. The coefficients of the dummy default-in-the-last-5-years are also significant (and positive), showing that a default in the last five years increases the rating difference between S\&P and Fitch in this case.

Analysing the rating difference between Moody's and Fitch, when the rating given by Moody's is higher than Fitch's rating $\left(\operatorname{Diff}_{-} U P_{i t}{ }^{M F}\right)$, we find significant values for two dependent variables, GDP growth (negative coefficient on two specifications) and external debt level (positive coefficients on all specifications). These results show that when GDP growth increases, the rating difference between these two agencies becomes smaller, whereas when the level of external debt increases, the gap between these two agencies increases.

When Moody's rating is lower than the rating from Fitch (Diff_D $D W_{i t}{ }^{M F}$ ), we find that the dummy variable representing a default in the last five years has a positive coefficient in all specifications. For this reason, if a default in the last five years occurred, the rating difference in this setting between Moody's and Fitch increases as well. 
Table III Summary of the full dataset, divided by the six target variables.

\begin{tabular}{|c|c|c|c|c|c|c|}
\hline & $D_{i f f} U P_{\mathrm{it}}{ }^{S F}$ & Diff_DW ${ }_{\mathrm{it}}{ }^{S F}$ & Diff_UP ${ }_{\mathrm{it}}^{M F}$ & Diff_DW ${ }_{\mathrm{it}}{ }^{M F}$ & Diff_UP ${ }_{\mathrm{it}}{ }^{S M}$ & Diff_DW $W_{\mathrm{it}}^{S M}$ \\
\hline No. of countries & 87 & 87 & 70 & 69 & 82 & 82 \\
\hline No. of years & 22 & 22 & 22 & 22 & 36 & 36 \\
\hline First and last year & $1994-2015$ & $1994-2015$ & $1994-2015$ & $1994-2015$ & $1980-2015$ & $1980-2015$ \\
\hline No. of observations & 1149 & 1194 & 903 & 851 & 1103 & 1165 \\
\hline \multicolumn{7}{|l|}{ Observations with: } \\
\hline Rating difference $=0$ & $898(78 \%)$ & $898(75 \%)$ & $606(67 \%)$ & $606(71 \%)$ & $764(69 \%)$ & $764(66 \%)$ \\
\hline Rating difference $=1$ & $221(19 \%)$ & $248(21 \%)$ & $223(25 \%)$ & $187(22 \%)$ & $247(22 \%)$ & $286(25 \%)$ \\
\hline Rating difference $=2$ & $30(3 \%)$ & $48(4 \%)$ & $74(8 \%)$ & $58(7 \%)$ & $92(8 \%)$ & $115(10 \%)$ \\
\hline $\begin{array}{l}\text { No. of observations } \\
\text { with a value: }\end{array}$ & & & & & & \\
\hline$G D P$ per capita & $1149(100 \%)$ & $1194(100 \%)$ & $903(100 \%)$ & $851(100 \%)$ & $1103(100 \%)$ & $1165(100 \%)$ \\
\hline $\begin{array}{l}\text { Real GDP growth } \\
\text { rate }\end{array}$ & $1148(100 \%)$ & $1194(100 \%)$ & $903(100 \%)$ & $851(100 \%)$ & $1103(100 \%)$ & $1165(100 \%)$ \\
\hline External debt & $841(73 \%)$ & $897(75 \%)$ & $685(76 \%)$ & $648(76 \%)$ & $701(64 \%)$ & $808(69 \%)$ \\
\hline Gov. gross debt & $1096(95 \%)$ & $1135(95 \%)$ & $865(96 \%)$ & $807(95 \%)$ & $1018(92 \%)$ & $1065(91 \%)$ \\
\hline Gov. net debt & $1046(91 \%)$ & $1085(91 \%)$ & $822(91 \%)$ & $770(90 \%)$ & $954(86 \%)$ & $1004(86 \%)$ \\
\hline Budget balance & $1112(97 \%)$ & $1153(97 \%)$ & $877(97 \%)$ & $824(97 \%)$ & $1057(96 \%)$ & $1104(95 \%)$ \\
\hline Structural balance & $1064(93 \%)$ & $1100(92 \%)$ & $842(93 \%)$ & $774(91 \%)$ & $970(88 \%)$ & $1028(88 \%)$ \\
\hline Inflation & $1147(100 \%)$ & $1191(100 \%)$ & $901(100 \%)$ & $848(100 \%)$ & $1100(100 \%)$ & $1160(100 \%)$ \\
\hline \multicolumn{7}{|l|}{ Default in the: } \\
\hline Last year & $312(27 \%)$ & $321(27 \%)$ & $164(18 \%)$ & $211(25 \%)$ & $268(24 \%)$ & $258(22 \%)$ \\
\hline Last two years & $349(30 \%)$ & $363(30 \%)$ & $190(21 \%)$ & $247(29 \%)$ & $311(28 \%)$ & $297(25 \%)$ \\
\hline Last five years & $419(36 \%)$ & $446(37 \%)$ & $248(27 \%)$ & $313(37 \%)$ & $379(34 \%)$ & $375(32 \%)$ \\
\hline Last ten years & $522(45 \%)$ & $539(45 \%)$ & $331(37 \%)$ & $366(43 \%)$ & $448(41 \%)$ & $454(39 \%)$ \\
\hline
\end{tabular}

Source: rating agencies and own calculations.

The variables gross debt and net debt also have significant values of opposite signs: the gross debt contributes negatively for the rating difference, reducing the rating difference when its value increases, while the net debt has positive coefficients, so its increase is expected to positively influence the magnitude of the rating difference. We need to better understand the opposite signs of these two variables, since they should be correlated to a certain degree. The 
separate regressions of the investment and speculative ratings may shed some light into this topic.

The results from regressing our dependent variable Diff_UP $P_{i t}^{S M}$ (when the S\&P rating is higher than Moody's rating), display significant results only for the dummy default variables. The dummy default-in-the-last-2-years has positive coefficients on all specifications, meaning that if a country defaults in the last two years, the rating gap between S\&P and Moody's will grow.

The results from regressing the last set of specifications, when the rating from $\mathrm{S} \& \mathrm{P}$ is lower than the rating from Moody's (Diff_ $U P_{i t}{ }^{S M}$ dependent variable), show that the budget balance, gross debt, GDP growth and GDP per capita variables all contribute to the rating difference in question. Those first three variables have statistically significant and positive coefficients, meaning that when one of those variables increase, the rating difference between S\&P and Moody's (Diff_UP $\left.{ }_{i t}{ }^{S M}\right)$ will increase as well. The coefficient of the GDP per capita variable is negative, so when its value increases, the rating gap between S\&P and Moody's becomes smaller.

The main results of running the ordered probit regressions with our full dataset are shown in Table IV. ${ }^{15}$

\footnotetext{
15 The full results are available on request.
} 
Table IV - Summary of the regressions of the ordered probit full dataset.

\begin{tabular}{|c|c|c|c|}
\hline & Significant variables & $\begin{array}{l}\text { Marginal Effect } \\
\text { Rating difference }=1\end{array}$ & $\begin{array}{l}\text { Marginal Effect } \\
\text { Rating difference }=2\end{array}$ \\
\hline \multirow[t]{2}{*}{ Diff_UP $P_{\mathrm{it}} S F$} & (-) Budget balance (4/4) & $-0.001 \%$ & $-0.00008 \%$ \\
\hline & $(+)$ Net debt (4/4) & $0.0004 \%$ & $0.00003 \%$ \\
\hline \multirow[t]{5}{*}{ Diff_DW $W_{\mathrm{it}}^{S F}$} & (-) GDP per capita $(16 / 16)$ & $-0.3 \%$ & $-0.03 \%$ \\
\hline & (-) External debt (16/16) & $-0.1 \%$ & $-0.01 \%$ \\
\hline & (+) Default last 1Y (1/4) & $12.3 \%$ & $1.9 \%$ \\
\hline & (+) Default last 2Y (1/4) & $11.5 \%$ & $1.7 \%$ \\
\hline & (+) Default last 5Y (4/4) & $10.1 \%-10.5 \%$ & $1.3 \%-1.5 \%$ \\
\hline \multirow[t]{2}{*}{$D i f f \_U P_{\mathrm{it}}^{M F}$} & (-) GDP growth (9/16) & $-0.9 \%--1 \%$ & $-0.2 \%$ \\
\hline & (+) External debt (16/16) & $0.1 \%-0.2 \%$ & $0.03 \%-0.04 \%$ \\
\hline \multirow[t]{4}{*}{$D i f f \_D W_{\mathrm{it}}^{M F}$} & (-) Gross debt (2/4) & $-0.2 \%$ & $-0.05 \%--0.06 \%$ \\
\hline & (+) Net debt (4/4) & $0.0003 \%$ & $0.00007 \%$ \\
\hline & (+) Default last 2Y (3/4) & $10.8 \%-11.4 \%$ & $2.9 \%-3 \%$ \\
\hline & (+) Default last $5 Y(4 / 4)$ & $11.3 \%-12.1 \%$ & $3 \%-3.2 \%$ \\
\hline \multirow[t]{4}{*}{$D i f f \_U P_{\mathrm{it}}{ }^{S M}$} & (+) Default last Y (1/4) & $6.1 \%$ & $2 \%$ \\
\hline & (+) Default last 2Y (4/4) & $8.1 \%-11.4 \%$ & $2.7 \%-3.5 \%$ \\
\hline & (+) Default last 5Y (1/4) & $12.9 \%$ & $3.9 \%$ \\
\hline & (+) Default last 10Y (1/4) & $12.7 \%$ & $3.6 \%$ \\
\hline \multirow[t]{4}{*}{$D i f f \_D W_{\mathrm{it}}^{S M}$} & (+) Budget balance (4/4) & $0.005 \%$ & $0.002 \%$ \\
\hline & $(+)$ Gross debt (4/4) & $0.2 \%$ & $0.07 \%$ \\
\hline & (+) GDP growth (4/16) & $0.8 \%$ & $0.2 \%$ \\
\hline & (-) GDP per capita (8/16) & $-0.3 \%$ & $-0.08 \%--0.09 \%$ \\
\hline
\end{tabular}

Note: Coefficient signs and number of significant regressions (besides the total number of run regressions) in parenthesis.

\subsubsection{Differentiation between investment and speculative ratings}

We will now report the ordered probit regression results when the observations used as input were divided into two subsets, depending on the value of the average rating given by the rating agency pair. The observations with a numeric average rating of 12 or more $^{16}$ were grouped in the investment-grade subset, whereas those with a numeric rating less than 12 were grouped in the speculative-grade subset.

\subsubsection{Investment-grade subset}

This section will analyse the results from the ordered probit regression when considering only observations with an investment-grade average rating. When compared with the full

\footnotetext{
${ }^{16}$ Corresponding to 'BBB-' for S\&P and Fitch or to 'Baa3' for Moody's.
} 
dataset, the investment-grade dataset had observations for a smaller number of countries, between 49 and 57 different countries. The adopted criteria of considering only those observations with an investment-grade average rating reduced as expected the number of observations for each target variable (all target variables had less than 800 observations). It's important to note a higher percentage of observations with the same rating (when compared with the full dataset) from each rating agency in this setting, reflecting a greater coherence between the studied rating agencies when considering investment-grade sovereigns. This may be explained by Livingston et al. (2007) opaqueness idea which associates bond split ratings with the opaqueness of the issuer. In this case, investment-grade sovereign issuers disclose more detailed information, allowing rating agencies to better evaluate their ability to service debt and therefore rating agencies will agree more often about a country's rating in this context, leading to a higher percentage of observations with a rating difference of 0 . Table $\mathrm{V}$ summarizes the dataset used in this section.

Our regression, when the $\mathrm{S} \& \mathrm{P}$ rating is higher than the rating from Fitch (Diff_UP ${ }_{i t} S F$ dependent variable), only yield significant results for one of the specifications (only one of the regressions show the budget balance variable as significant). This specification shows a positive correlation between government net debt and the observed rating difference, when the ratings from S\&P and Fitch are investment-grade.

When the rating from $S \& \mathrm{P}$ is lower than the one from Fitch $\left(\operatorname{Diff}_{-} D W_{i t}{ }^{S F}\right)$, the obtained results for all specifications show a negative correlation between GDP per capita and the rating difference. This means that when GDP per capita increases, the rating difference is reduced. Only one of the regressions in this setting shows a significant and positive default dummy variable (the last year one).

The regressions of our dependent variable Diff_UP ${ }_{i t}{ }^{M F}$ (rating from Moody's higher than the one from Fitch, with the average classified as investment-grade) showed a positive and negative correlation between the rating difference and, respectively, GDP per capita and inflation. In this case, when GDP per capita increases, the rating gap increases, whereas with an inflation increase, the rating divergence between those two agencies will diminish.

While analysing the results when we regress the Diff_D $W_{i t}{ }^{M F}$ (rating difference when the rating from Moody's is lower than the rating from Fitch), we only find one of the regressions showing a significant coefficient for the government gross debt predicting variable. 
Table V - Summary of the investment-grade dataset, divided by the six target variables.

\begin{tabular}{|c|c|c|c|c|c|c|}
\hline & Diff_UP $P_{\mathrm{it}}^{S F}$ & $D i f f \_D W_{\mathrm{it}}^{S F}$ & $D_{i f f} U P_{\mathrm{it}}^{M F}$ & Diff_D $W_{\mathrm{it}}^{M F}$ & Diff_UP $P_{\mathrm{it}}^{S M}$ & $\overline{D i f f \_D W_{\mathrm{it}}{ }^{S M}}$ \\
\hline No. of countries & 57 & 56 & 50 & 49 & 52 & 52 \\
\hline No. of years & 22 & 22 & 22 & 22 & 36 & 36 \\
\hline First and last year & $1994-2015$ & 1994-2015 & 1994-2015 & 1994-2015 & $1980-2015$ & $1980-2015$ \\
\hline No. of observations & 773 & 759 & 665 & 555 & 746 & 795 \\
\hline \multicolumn{7}{|l|}{ Observations with: } \\
\hline Rating difference $=0$ & $634(82 \%)$ & $634(84 \%)$ & $466(70 \%)$ & $466(84 \%)$ & $568(76 \%)$ & $568(71 \%)$ \\
\hline Rating difference $=1$ & $124(16 \%)$ & $112(15 \%)$ & $145(22 \%)$ & $64(12 \%)$ & $124(17 \%)$ & $157(20 \%)$ \\
\hline Rating difference $=2$ & $15(2 \%)$ & $13(2 \%)$ & $54(8 \%)$ & $25(5 \%)$ & $54(7 \%)$ & $70(9 \%)$ \\
\hline \multicolumn{7}{|l|}{$\begin{array}{l}\text { No. of observations } \\
\text { with a value: }\end{array}$} \\
\hline GDP per capita & $\begin{array}{l}773 \\
(100 \%)\end{array}$ & $759(100 \%)$ & $665(100 \%)$ & $555(100 \%)$ & $746(100 \%)$ & $795(100 \%)$ \\
\hline $\begin{array}{l}\text { Real GDP growth } \\
\text { rate }\end{array}$ & $\begin{array}{l}772 \\
(100 \%)\end{array}$ & $759(100 \%)$ & $665(100 \%)$ & $555(100 \%)$ & $746(100 \%)$ & $795(100 \%)$ \\
\hline External debt & $491(64 \%)$ & $491(65 \%)$ & $462(69 \%)$ & $370(67 \%)$ & $378(51 \%)$ & $472(59 \%)$ \\
\hline Gov. gross debt & $750(97 \%)$ & $735(97 \%)$ & $655(99 \%)$ & $544(98 \%)$ & $693(93 \%)$ & $734(92 \%)$ \\
\hline Gov. net debt & $700(91 \%)$ & $675(89 \%)$ & $605(91 \%)$ & $499(90 \%)$ & $641(86 \%)$ & $673(85 \%)$ \\
\hline Budget balance & $753(97 \%)$ & $738(97 \%)$ & $658(99 \%)$ & $547(99 \%)$ & $717(96 \%)$ & $760(96 \%)$ \\
\hline Structural balance & $727(94 \%)$ & $713(94 \%)$ & $643(97 \%)$ & $528(95 \%)$ & $661(89 \%)$ & $709(89 \%)$ \\
\hline Inflation & $\begin{array}{l}772 \\
(100 \%)\end{array}$ & $759(100 \%)$ & $665(100 \%)$ & $555(100 \%)$ & $746(100 \%)$ & $795(100 \%)$ \\
\hline \multicolumn{7}{|l|}{ Default in the: } \\
\hline Last year & $74(10 \%)$ & $66(9 \%)$ & $46(7 \%)$ & $42(8 \%)$ & $56(8 \%)$ & $56(7 \%)$ \\
\hline Last two years & $87(11 \%)$ & $76(10 \%)$ & $55(8 \%)$ & $52(9 \%)$ & $65(9 \%)$ & $63(8 \%)$ \\
\hline Last five years & $117(15 \%)$ & $104(14 \%)$ & $77(12 \%)$ & $73(13 \%)$ & $88(12 \%)$ & $87(11 \%)$ \\
\hline Last ten years & $177(23 \%)$ & $153(20 \%)$ & $124(19 \%)$ & $104(19 \%)$ & $127(17 \%)$ & $130(16 \%)$ \\
\hline
\end{tabular}

Source: rating agencies and own calculations.

All the regressions of the Diff_UP ${ }_{i t}^{S M}$ target variable (rating difference when the rating from S\&P is higher than the rating from Moody's, and, on average, both ratings are investmentgrade) show a significant negative correlation between external debt and the rating difference, leading to a smaller rating difference when the level of external debt rises. 
The last dependent variable, Diff_ $D W_{i t}{ }^{S M}$, yield significant results when regressed against our predicting variables: both budget balance and government gross debt have significant positive coefficients ${ }^{17}$, meaning that an increase of those variables will lead to an increase in the rating difference between S\&P and Moody's, when the rating of the first is lower than the rating of the latter.

The GDP growth predicting variable also has significant positive coefficients on two of the four regressed specifications, showing an effect on the rating difference similar to the described effect of the budget balance and government gross debt on the rating gap. We also observe statistically significant and negative coefficients for two of the default dummy variables $^{18}$, meaning that the existence of a default in the last year or two will contribute to a smaller rating difference between S\&P and Moody's in this case.

Table VI summarizes the significant results obtained when regressing the investmentgrade subset. ${ }^{19}$

Table VI - Summary of the regressions of the ordered probit investment-grade subset.

\begin{tabular}{|c|c|c|c|}
\hline & Significant variables & $\begin{array}{l}\text { Marginal Effect } \\
\text { Rating difference }=1\end{array}$ & $\begin{array}{l}\text { Marginal Effect } \\
\text { Rating difference }=2\end{array}$ \\
\hline \multirow[t]{2}{*}{ Diff_UP ${ }_{\mathrm{it}}^{S F}$} & (-) Budget balance (1/4) & $-0.0005 \%$ & $-0.00002 \%$ \\
\hline & $(+)$ Net debt (4/4) & $0.0003 \%$ & $0.00001 \%$ \\
\hline \multirow[t]{2}{*}{ Diff_DW $W_{\mathrm{it}}^{S F}$} & (-) GDP per capita (15/16) & $-0.2 \%$ & $-0.005 \%--0.007 \%$ \\
\hline & (+) Default last 1Y (1/4) & $12.6 \%$ & $0.52 \%$ \\
\hline \multirow[t]{2}{*}{ Diff_UP $P_{\mathrm{it}}{ }^{M F}$} & (+) GDP per capita $(12 / 16)$ & $0.4 \%$ & $0.05 \%-0.06 \%$ \\
\hline & (-) Inflation (16/16) & $-2.0 \%--2.3 \%$ & $-0.2 \%--0.3 \%$ \\
\hline Diff_D $W_{\mathrm{it}}{ }^{M F}$ & (-) Gross debt (1/4) & $-0.1 \%$ & $-0.02 \%$ \\
\hline Diff_UP $P_{\mathrm{it}}{ }^{S M}$ & (-) External debt (16/16) & $-0.2 \%--0.3 \%$ & $-0.04 \%$ \\
\hline \multirow[t]{5}{*}{ Diff_DW $W_{\mathrm{it}}{ }^{S M}$} & (+) Budget balance (4/4) & $0.004 \%$ & $0.0008 \%$ \\
\hline & $(+)$ Gross debt (4/4) & $0.2 \%$ & $0.04 \%$ \\
\hline & (+) GDP growth (8/16) & $1.1 \%-1.3 \%$ & $0.2 \%-0.3 \%$ \\
\hline & (-) Default last 1Y (4/4) & $-10.9 \%--11.8 \%$ & $-1.6 \%--1.8 \%$ \\
\hline & (-) Default last $2 Y(4 / 4)$ & $-8.4 \%--9.3 \%$ & $-1.3 \%--1.5 \%$ \\
\hline
\end{tabular}

Note: Coefficient signs and number of significant regressions (besides the total number of run regressions) in parenthesis.

\footnotetext{
${ }^{17}$ With a significance level of $1 \%$ for all the relevant regressions.

${ }^{18}$ Default in the last year and in the last two years.

${ }^{19}$ The full results are available on request.
} 


\subsubsection{Speculative-grade subset}

Lastly, the results from the ordered probit regression using the same specifications will be analysed, but this time using a subset of the full dataset composed only by observations with a speculative-grade average rating. This speculative-grade subset has observations for at least 38 countries $^{20}$ and comprehends the period from 1992 to 2015 . We have much less observations (between 238 and 435 observations) for the speculative-grade dataset when compared with the investment-grade and full datasets.

By analysing Table VII we can observe that the same rating can only be found on $70 \%$ of the observations for the Diff_UP ${ }_{i t}{ }^{S F}$ target variable, reaching as low as $47 \%$ of the observations for the rating differences between Moody's and Fitch, when the rating from the first is lower than the rating from the latter. This fact reflects how opaque speculative-grade sovereigns are and how difficult is for credit rating agencies to assess the real capability of these sovereigns to service their debt. This lack of transparency leads to the information available to rating agencies having poor quality and increases the probability of a split rating (Al-Sakka and ap Gwilym, 2010).

The first regressions have the Diff_ $U P_{i t}{ }^{S F}$ as the dependent variable and produce significant results for the budget balance and government net debt variables (only one of the regressions with this target variable show the dummy default-in-the-last-5-years variable as significant). The budget balance coefficient is negative, leading to a smaller rating difference between S\&P and Fitch when the budget balance grows. Government net debt has the opposite effect on the described rating difference: when it increases, the rating disparity between those two agencies increases as well.

With regards to the obtained results when regressing the Diff_D $W_{i t}{ }^{S F}$ variable, it is possible to observe that government net debt, GDP growth, external debt level and the dummy default-in-the-last-10-years variables all have an effect on the rating difference between S\&P and Fitch, when the rating from the first is lower than the rating from the latter. The government net debt variable has a positive coefficient, increasing the rating difference when its value increases. The remaining significant variables (GDP growth, external debt level and the dummy default variable) have negative coefficients, so when their value increases (or becomes one, in the case of the dummy variable), the rating difference between S\&P and Fitch shrinks.

\footnotetext{
${ }^{20}$ For the Diff_DW ${ }_{i t}^{M F}$ target variable; the remaining target variables include observations for more than 50 countries.
} 
Table VII - Summary of the speculative-grade dataset, divided by the six target variables.

\begin{tabular}{|c|c|c|c|c|c|c|}
\hline & $D i f f \_U P_{\mathrm{it}}{ }^{S F}$ & Diff_DW $W_{\mathrm{it}}^{S F}$ & Diff_UP ${ }_{\mathrm{it}}^{M F}$ & $D i f f \_D W_{\mathrm{it}}^{M F}$ & Diff_UP ${ }_{\mathrm{it}}^{S M}$ & Diff_D $W_{\mathrm{it}}{ }^{S M}$ \\
\hline No. of countries & 54 & 53 & 42 & 38 & 50 & 51 \\
\hline No. of years & 22 & 22 & 22 & 22 & 23 & 24 \\
\hline First and last year & 1994-2015 & 1994-2015 & $1994-2015$ & 1994-2015 & $1993-2015$ & $1992-2015$ \\
\hline No. of observations & 376 & 435 & 238 & 296 & 357 & 370 \\
\hline Observations with: & & & & & & \\
\hline Rating difference $=0$ & $264(70 \%)$ & $264(61 \%)$ & $140(59 \%)$ & $140(47 \%)$ & $196(55 \%)$ & $196(53 \%)$ \\
\hline Rating difference $=1$ & $97(26 \%)$ & $136(31 \%)$ & $78(33 \%)$ & $123(42 \%)$ & $123(34 \%)$ & $129(35 \%)$ \\
\hline Rating difference $=2$ & $15(4 \%)$ & $35(8 \%)$ & $20(8 \%)$ & $33(11 \%)$ & $38(11 \%)$ & $45(12 \%)$ \\
\hline $\begin{array}{l}\text { No. of observations } \\
\text { with a value: }\end{array}$ & & & & & & \\
\hline GDP per capita & $376(100 \%)$ & $435(100 \%)$ & $238(100 \%)$ & $296(100 \%)$ & $357(100 \%)$ & $370(100 \%)$ \\
\hline $\begin{array}{l}\text { Real GDP growth } \\
\text { rate }\end{array}$ & $376(100 \%)$ & $435(100 \%)$ & $238(100 \%)$ & $296(100 \%)$ & $357(100 \%)$ & $370(100 \%)$ \\
\hline External debt & $350(93 \%)$ & $406(93 \%)$ & $223(94 \%)$ & $278(94 \%)$ & $323(90 \%)$ & $336(91 \%)$ \\
\hline Gov. gross debt & $346(92 \%)$ & $400(92 \%)$ & $210(88 \%)$ & $263(89 \%)$ & $325(91 \%)$ & $331(89 \%)$ \\
\hline Gov. net debt & $346(92 \%)$ & $410(94 \%)$ & $217(91 \%)$ & $271(92 \%)$ & $313(88 \%)$ & $331(89 \%)$ \\
\hline Budget balance & $359(95 \%)$ & $415(95 \%)$ & $219(92 \%)$ & $277(94 \%)$ & $340(95 \%)$ & $344(93 \%)$ \\
\hline Structural balance & $337(90 \%)$ & $387(89 \%)$ & $199(84 \%)$ & $246(83 \%)$ & $309(87 \%)$ & $319(86 \%)$ \\
\hline Inflation & $375(100 \%)$ & $432(99 \%)$ & $236(99 \%)$ & $293(99 \%)$ & $354(99 \%)$ & $365(99 \%)$ \\
\hline \multicolumn{7}{|l|}{ Default in the: } \\
\hline Last year & $238(63 \%)$ & $255(59 \%)$ & $118(50 \%)$ & $169(57 \%)$ & $212(59 \%)$ & $202(55 \%)$ \\
\hline Last two years & $262(70 \%)$ & $287(66 \%)$ & $135(57 \%)$ & $195(66 \%)$ & $246(69 \%)$ & $234(63 \%)$ \\
\hline Last five years & $302(80 \%)$ & $342(79 \%)$ & $171(72 \%)$ & $240(81 \%)$ & $291(82 \%)$ & $288(78 \%)$ \\
\hline Last ten years & $345(92 \%)$ & $986(89 \%)$ & $207(87 \%)$ & $262(89 \%)$ & $321(90 \%)$ & $324(88 \%)$ \\
\hline
\end{tabular}

Source: rating agencies and own calculations.

Only one of the specifications yield significant results when regressing the Diff_UP ${ }_{i t}{ }^{M F}$ variable (rating difference between Moody's and Fitch, with a higher rating from the first agency). External debt has positive and significant coefficients on two of the regressions, therefore when its value increases, the analysed rating difference increases as well. Two of the four dummy default variables (default in the last year and in the last five years) have significant 
negative coefficients, thus when a default happened in the last year or in the last five years, the rating difference will get smaller.

The regression of the Diff_ $D W_{i t}^{M F}$ target variable against the different specifications of predicting variables highlights the effect of government gross debt and inflation on the rating difference between Moody's and Fitch, when the first is lower than the latter (the dummy default-in-the-last-10-years variable only yielded significant and negative results for one of the regressions). Both gross debt and inflation contribute negatively to the rating gap, therefore, the rating difference will shrink if one of those variables increases.

Table VIII - Summary of the regressions of the ordered probit speculative-grade subset.

\begin{tabular}{|c|c|c|c|}
\hline & $\begin{array}{l}\text { Significant variables } \\
\text { (Coefficient sign) }\end{array}$ & $\begin{array}{l}\text { Marginal Effect } \\
\text { Rating difference }=1\end{array}$ & $\begin{array}{l}\text { Marginal Effect } \\
\text { Rating difference }=2\end{array}$ \\
\hline \multirow[t]{3}{*}{ Diff_UP $P_{\mathrm{it}}{ }^{S F}$} & (-) Budget balance (4/4) & $-0.002 \%$ & $-0.0001 \%$ \\
\hline & (+) Net debt (4/4) & $0.2 \%$ & $0.01 \%$ \\
\hline & (-) Default last 5Y (1/4) & $-17.3 \%$ & $-2.8 \%$ \\
\hline \multirow[t]{4}{*}{ Diff_DW $W_{\mathrm{it}}^{S F}$} & $(+)$ Net debt (4/4) & $0.2 \%$ & $0.04 \%$ \\
\hline & (-) GDP growth (15/16) & $-1.2 \%--1.3 \%$ & $-0.3 \%--1 \%$ \\
\hline & (-) External debt (15/16) & $-0.1 \%--0.2 \%$ & $-0.03 \%--0.07 \%$ \\
\hline & (-) Default last 10Y (3/4) & $-11.7 \%--12.7 \%$ & $-3.8 \%--5.9 \%$ \\
\hline \multirow[t]{3}{*}{ Diff_UP ${ }_{\mathrm{it}}{ }^{M F}$} & $(+)$ External debt (2/16) & $0.2 \%$ & $0.05 \%$ \\
\hline & (-) Default last Y (1/4) & $-13.2 \%$ & $-3.1 \%$ \\
\hline & (-) Default last $5 Y(1 / 4)$ & $-20.4 \%$ & $-5.6 \%$ \\
\hline \multirow[t]{3}{*}{ Diff_DW $W_{\mathrm{it}}^{M F}$} & (-) Gross debt (4/4) & $-0.3 \%$ & $-0.1 \%--0.2 \%$ \\
\hline & (-) Inflation (4/4) & $-0.3 \%$ & $-0.1 \%--0.2 \%$ \\
\hline & (-) Default last 10Y (1/4) & $-11 \%$ & $-10.2 \%$ \\
\hline$D i f f \_U P_{\mathrm{it}}{ }^{S M}$ & (-) Net debt (4/4) & $-0.2 \%$ & $-0.06 \%$ \\
\hline \multirow[t]{3}{*}{ Diff_DW ${ }_{\mathrm{it}}{ }^{S M}$} & (+) Budget balance (3/4) & $0.007 \%$ & $0.001 \%$ \\
\hline & (-) GDP per capita (12/16) & $-0.4 \%--0.5 \%$ & $-0.08 \%--0.1 \%$ \\
\hline & (-) External debt (4/16) & $-0.2 \%$ & $-0.05 \%$ \\
\hline
\end{tabular}

Note: Coefficient signs and number of significant regressions (besides the total number of run regressions) in parenthesis.

All the ordered probit regressions run with Diff_UP ${ }_{i t}{ }^{S M}$ as the dependent variable show that the government net debt contributes negatively to the rating difference, when the S\&P rating is higher than the rating from Moody's. As a result, when the government net debt increases, the rating gap between S\&P and Moody's shrinks.

The results from regressing the Diff_ $D W_{i t}{ }^{S M}$ target variable show a positive and a negative correlation between the rating difference (when the rating from S\&P is lower than the one from Moody's) and, respectively, the budget balance on one hand, and GDP per capita and 
external debt on the other hand. For this reason, when the budget balance increases, the considered rating gap increases; whereas, when GDP per capita or external debt increase, the same rating gap decreases.

Table VIII summarizes the significant results obtained when regressing the speculative-grade subset $^{21}$.

\subsection{Simple probit panel results}

When regressing our target variables (Diff_UP ${ }_{i t}^{S F}, \quad$ Diff_D $W_{i t}{ }^{S F}, D_{i f f} U P_{i t}{ }^{M F}$, $D i f f \_D W_{i t}{ }^{M F}, D i f f \_U P_{i t}{ }^{S M}$ and $D i f f \_D W_{i t}{ }^{S M}$ ) with the ordered probit framework, we found that only $3 \%$ to $10 \%$ of our observations had a rating gap of 2-notches or higher (this can be seen on the summary of Table III). Therefore, we decided to run a simple probit regression for the same observations subsets already used: we first considered the full dataset, and afterwards we split it into two subsets (an investment-grade and a speculative-grade dataset) depending on the average rating of the observation.

\subsubsection{Full sample}

Regressing our target variables with a simple probit model produced significant results for all specifications. Our regressions, when the ratings from S\&P are higher than Fitch own ratings, show that both budget balance and government net debt have an effect on the rating difference between those two agencies. In the first case, when the budget balance grows, the rating difference shrinks, whereas when the government net debt increases, the rating difference will increase as well.

The results of regressing Diff_D $D W_{i t}{ }^{S F}$ highlight the influence of GDP per capita and the dummy default-in-the-last-5-years variable. ${ }^{22}$ When GDP per capita grows, S\&P and Fitch will update their ratings, resulting in a smaller rating difference. The opposite happens when there is a default in the last five years: in this case, the rating disagreement between those two agencies will grow.

Our regressions also produce significant results when a positive rating difference between Moody's and Fitch (represented by the Diff_UP ${ }_{i t}{ }^{M F}$ dependent variable) exists. All the regressions show a positive correlation between external debt and the rating difference (so when external debt increases, the rating gap gets bigger as well).

\footnotetext{
${ }^{21}$ The full results are available on request.

${ }^{22}$ The last specification also yields significant and positive coefficients for the dummy default-in-the-last-year and default-in-the-last-2-years variables.
} 
The structural balance variable also impacts on the rating difference, because of its significant and negative coefficients. When structural balance increases for a given country, we can expect the rating difference between Moody's and Fitch to become smaller.

The regressions of our Diff_D $D W_{i t}{ }^{M F}$ dependent variable show that government net debt and two of the dummy default variables are all positively correlated with the rating difference. As a consequence, when a country's net debt increases or a default happens in the last two or five years, we may expect a bigger rating difference between Moody's and Fitch.

The results of regressing the Diff_UP ${ }_{i t}^{S M}$ dependent variable only produce significant coefficients for one of the specifications. In specification (4), the external debt predicting variable had a significant and negative coefficient for all the regressions, so when its value increased, the rating difference between S\&P and Moody's would become smaller. Two regressions of this specification also exposed the positive correlation between a default in the last five or 10 years and an increase of the rating difference.

Finally, the simple probit regressions of the Diff_D $D W_{i t}^{S M}$ variable reveal a positive correlation between the rating difference and each one of the budget balance, government gross debt and GDP growth dependent variables. Therefore, when one of the previous variables increases, one may expect a bigger rating gap between S\&P and Moody's. In contrast, and derived from the significant and negative coefficients of the GDP per capita variable, when its value increases, one may expect the ratings from S\&P and Moody's to converge.

\subsubsection{Differentiation between investment and speculative ratings}

\subsubsection{Investment-grade subset}

The regressions of our Diff_UP $P_{i t} S F$ target variable only showed positive and significant coefficients for the government net debt variable. For this reason, when the government net debt increases, one can expect a bigger rating difference between S\&P and Fitch.

When analysing the results of regressing our observations when the rating from S\&P was lower or equal to the rating from Fitch (i.e., Diff_D $D W_{i t}^{S F}$ dependent variable), we found that both GDP per capita and inflation have significant coefficient values with opposite signs ${ }^{23}$. While an increase of GDP per capita will decrease the rating difference, an inflation increase will contribute to a bigger rating difference between those two agencies.

Our regressions of the variable Diff_UP ${ }_{i t}{ }^{M F}$ showed that budget balance, structural balance, inflation and the dummy variable default-in-the-last-10-years all have negative and

\footnotetext{
${ }^{23}$ Only one of the regressions showed a positive coefficient for the dummy variable representing a country default in the last year.
} 
significant coefficients. Thus, with an increase of those variables (or the existence of a default in the last ten years), one may expect a reduction in the rating gap between Moody's and Fitch, in this context. We also found two regressions producing positive and significant coefficients for the GDP per capita variable.

By regressing our observations when Moody's rating is lower than Fitch own rating (i.e., when regressing $D i f f \_D W_{i t}^{M F}$ ), we found that government net debt had positive coefficients for all the regressions using it. On the other hand, only one of the regressions disclosed a negative coefficient for the government gross debt variable. With this in mind, one may expect an increase of the rating difference when net debt increases, while an increase of the government gross debt will shrink the rating difference.

We find that both external debt and GDP per capita variables have significant and negative coefficients when regressing those observations with a higher rating from S\&P than from Moody's (Diff_UP ${ }_{i t}{ }^{S M}$ dependent variable). As a result, when one of those variables increases, the rating gap between S\&P and Moody's will get smaller.

Lastly, our regressions of the Diff_D $D W_{i t}^{S M}$ target variable yield significant results for three of the four dummy default variables (default in the last year, two and five years), structural balance, GDP growth, budget balance and government gross debt variables. The structural balance and the default in the last year/2-years/5-years dummy predicting variables have a negative coefficient, leading to a smaller rating difference between S\&P and Moody's when they increase. On the other hand, the remaining variables (GDP growth, budget balance and the government gross debt) have positive coefficients, increasing the considered rating gap when they increase.

\subsubsection{Speculative-grade subset}

Our simple probit regressions of the speculative-grade dataset produced significant results across all the sovereign rating difference target variables.

By regressing the Diff_UP ${ }_{i t}^{S F}$ target variable with the speculative-grade dataset, we find that the budget balance and government net debt variables both have significant coefficients ${ }^{24}$ : when the budget balance grows, the rating difference between S\&P and Fitch becomes smaller, whereas when the government net debt grows, the same rating gap is expected to grow as well.

The results of regressing the Diff_D $W_{i t}^{S F}$ target variable show that GDP growth and three of the four dummy default variables contribute to a smaller rating difference between S\&P and

\footnotetext{
${ }^{24}$ Two of these regressions also show significant and negative coefficients for the dummy variables representing a default in the last two and five years.
} 
Fitch, when the rating from the first is lower than the rating from the latter, whereas the government net debt variable has a significant and positive correlation with the rating difference, triggering a bigger rating difference when its value grows.

In contrast to the regressions of the great majority of our target variables, the simple probit regressions of the Diff_ $U P_{i t}{ }^{M F}$ variable only produced significant coefficients for two of the regressions: the negative coefficients of the dummy variables representing a default in the last year and in the last five years show how a default in those past periods will contribute to a smaller rating gap between Moody's and Fitch, when the rating from the first is higher than the rating from the latter.

All regressions of the Diff_ $D W_{i t}^{M F}$ target variable show that an inflation increase lead to a smaller rating difference when the rating from Moody's is lower than the rating from Fitch. The regressions which used the specification with the structural balance variable also showed a positive and significant correlation between external debt and the rating difference. Thus, when external debt increases, the rating divergence between Moody's and Fitch will grow.

When running our simple probit regressions for the observations with the rating from S\&P higher than Moody's rating, we find that government net debt has a negative coefficient, so when its value grows, our target variable Diff_UP ${ }_{i t}{ }^{S M}$ will become smaller.

Lastly, we analyse the result of our simple probit regressions of the Diff_D $W_{i t}{ }^{S M}$ variable with the speculative-grade dataset. These regressions show that both GDP per capita and government gross debt variables have statistically significant coefficients. In the first case, the negative coefficients of GDP per capita indicate that when its value increases, the rating difference shrinks, whereas in the latter case, the positive coefficients of the government gross debt variable show that when gross debt gets bigger, the rating difference, when the rating from $\mathrm{S} \& \mathrm{P}$ is lower than the rating from Moody's, also increases.

The following table summarises the results from the different regressions run for all specifications and datasets for random-effects ordered and simple probit. 
Table IX - Comparison of the results obtained with the random-effects ordered and simple probit estimations for the full, investment-grade and speculative-grade datasets.

\begin{tabular}{|c|c|c|c|c|c|c|}
\hline & \multicolumn{2}{|c|}{ Full dataset } & \multicolumn{2}{|c|}{ Investment-grade dataset } & \multicolumn{2}{|c|}{ Speculative-grade dataset } \\
\hline $\begin{array}{l}\text { Significant } \\
\text { variables }\end{array}$ & Ordered probit results & Simple probit results & Ordered probit results & Simple probit results & Ordered probit results & Simple probit results \\
\hline$D i f f \_U P_{\mathrm{it}}^{S F}$ & $\begin{array}{l}\text { (-) Budget balance (4/4) } \\
(+) \text { Net debt (4/4) }\end{array}$ & $\begin{array}{l}\text { (-) Budget balance (4/4) } \\
(+) \text { Net debt (4/4) }\end{array}$ & $\begin{array}{l}\text { (-) Budget balance (1/4) } \\
(+) \text { Net debt }(4 / 4)\end{array}$ & (+) Net debt (4/4) & $\begin{array}{l}\text { (-) Budget balance (4/4) } \\
(+) \text { Net debt (4/4) } \\
\text { (-) Default last 5Y (1/4) }\end{array}$ & $\begin{array}{l}\text { (-) Budget balance (3/4) } \\
(+) \text { Net debt (4/4) } \\
\text { (-) Default last 2Y (1/4) } \\
\text { (-) Default last 5Y (1/4) }\end{array}$ \\
\hline$D i f f \_D W_{\mathrm{it}}{ }^{S F}$ & $\begin{array}{l}\text { (-) GDP per capita (16/16) } \\
\text { (-) External debt (16/16) } \\
\text { (+) Default last 1Y (1/4) } \\
\text { (+) Default last 2Y (1/4) } \\
\text { (+) Default last 5Y (4/4) }\end{array}$ & $\begin{array}{l}\text { (-) GDP per capita (16/16) } \\
\text { (+) Default last Y (1/4) } \\
\text { (+) Default last } 2 Y(1 / 4) \\
\text { (+) Default last } 5 Y(4 / 4)\end{array}$ & $\begin{array}{l}\text { (-) GDP per capita (15/16) } \\
\text { (+) Default last } 1 Y(1 / 4)\end{array}$ & $\begin{array}{l}\text { (-) GDP per capita (12/16) } \\
(+) \text { Inflation (13/16) } \\
\text { (+) Default last Y (1/4) }\end{array}$ & $\begin{array}{l}\text { (+) Net debt (4/4) } \\
(-) \text { External debt }(15 / 16) \\
(-) \text { GDP growth }(15 / 16) \\
(-) \text { Default last } 10 \mathrm{Y}(3 / 4)\end{array}$ & $\begin{array}{l}\text { (+) Net debt (4/4) } \\
\text { (-) GDP growth (15/16) } \\
\text { (-) Default last Y (2/4) } \\
\text { (-) Default last 2Y (2/4) } \\
\text { (-) Default last 10Y (4/4) }\end{array}$ \\
\hline$D i f f \_U P_{\mathrm{it}}{ }^{M F}$ & $\begin{array}{l}\text { (-) GDP growth (9/16) } \\
(+) \text { External debt }(16 / 16)\end{array}$ & $\begin{array}{l}\text { (-) Structural balance (3/4) } \\
(+) \text { External debt }(16 / 16)\end{array}$ & $\begin{array}{l}\text { (+) GDP per capita (12/16) } \\
(-) \text { Inflation }(16 / 16)\end{array}$ & $\begin{array}{l}\text { (+) GDP per capita (2/16) } \\
\text { (-) Inflation (13/16) } \\
\text { (-) Budget balance (1/4) } \\
\text { (-) Structural balance (4/4) } \\
\text { (-) Default last 5Y (4/4) }\end{array}$ & $\begin{array}{l}\text { (+) External debt (2/16) } \\
(-) \text { Default last Y (1/4) } \\
(-) \text { Default last } 5 Y(1 / 4)\end{array}$ & $\begin{array}{l}\text { (-) Default last Y (1/4) } \\
\text { (-) Default last 5Y (1/4) }\end{array}$ \\
\hline
\end{tabular}




\begin{tabular}{|c|c|c|c|c|c|c|}
\hline \multirow[b]{2}{*}{$\begin{array}{l}\text { Significant } \\
\text { variables }\end{array}$} & \multicolumn{2}{|c|}{ Full dataset } & \multicolumn{2}{|c|}{ Investment-grade dataset } & \multicolumn{2}{|c|}{ Speculative-grade dataset } \\
\hline & Ordered probit results & Simple probit results & Ordered probit results & Simple probit results & Ordered probit results & Simple probit results \\
\hline Diff_D $W_{\mathrm{it}}^{M F}$ & $\begin{array}{l}\text { (-) Gross debt (2/4) } \\
\text { (+) Net debt (4/4) } \\
\text { (+) Default last 2Y (3/4) } \\
\text { (+) Default last 5Y (4/4) }\end{array}$ & $\begin{array}{l}\text { (+) Net debt (4/4) } \\
(+) \text { Default last 2Y (3/4) } \\
\text { (+) Default last 5Y (4/4) }\end{array}$ & (-) Gross debt (1/4) & $\begin{array}{l}\text { (-) Gross debt (1/4) } \\
(+) \text { Net debt }(4 / 4)\end{array}$ & $\begin{array}{l}\text { (-) Gross debt (4/4) } \\
\text { (-) Inflation (4/4) } \\
\text { (-) Default last 10Y (1/4) }\end{array}$ & $\begin{array}{l}\text { (+) External debt (4/16) } \\
(-) \text { Inflation }(16 / 16)\end{array}$ \\
\hline$D i f f \_U P_{\mathrm{it}}{ }^{S M}$ & $\begin{array}{l}\text { (+) Default last Y (1/4) } \\
(+) \text { Default last } 2 Y(4 / 4) \\
(+) \text { Default last } 5 Y(1 / 4) \\
(+) \text { Default last } 10 Y(1 / 4)\end{array}$ & $\begin{array}{l}\text { (-) External debt (4/16) } \\
\text { (+) Default last 5Y (1/4) } \\
\text { (+) Default last 10Y (1/4) }\end{array}$ & (-) External debt (16/16) & $\begin{array}{l}\text { (-) External debt (16/16) } \\
\text { (-) GDP per capita }(8 / 16)\end{array}$ & (-) Net debt (4/4) & (-) Net debt (4/4) \\
\hline$D i f f \_D W_{\mathrm{it}}^{S M}$ & $\begin{array}{l}\text { (+) Budget balance } \\
\text { (+) Gross debt } \\
\text { (+) GDP growth } \\
\text { (-) GDP per capita }\end{array}$ & $\begin{array}{l}\text { (+) Budget balance (4/4) } \\
(+) \text { Gross debt }(4 / 4) \\
(+) \text { GDP growth }(4 / 16) \\
\text { (-) GDP per capita (12/16) }\end{array}$ & $\begin{array}{l}\text { (+) Budget balance (4/4) } \\
\text { (+) Gross debt (4/4) } \\
\text { (+) GDP growth (8/16) } \\
\text { (-) Default last 1Y (4/4) } \\
\text { (-) Default last 2Y (4/4) }\end{array}$ & $\begin{array}{l}\text { (+) Budget balance (4/4) } \\
\text { (-) Structural balance (2/4) } \\
\text { (+) Gross debt (4/4) } \\
\text { (+) GDP growth (13/16) } \\
\text { (-) Default last Y (4/4) } \\
\text { (-) Default last 2Y (4/4) } \\
\text { (-) Default last 5Y (4/4) }\end{array}$ & $\begin{array}{l}\text { (-) External debt (4/16) } \\
\text { (+) Budget balance (3/4) } \\
\text { (-) GDP per capita (12/16) }\end{array}$ & $\begin{array}{l}\text { (+) Gross debt }(4 / 4) \\
(-) \text { GDP per capita }(12 / 16)\end{array}$ \\
\hline
\end{tabular}

Note: Coefficient signs and number of significant regressions (besides the total number of run regressions) in parenthesis. 


\section{Conclusion}

By regressing the rating differences of the three main rating agencies with both an ordered and a simple probit random-effects model, we find some significant results, indicating the influence of some of our explanatory variables on those rating differences.

We used an ordered probit model, due to both the existence of rating differences above two notches and Al-Sakka and ap Gwilym (2010) approach to the split ratings topic. Nonetheless, and as a result of a lower percentage of rating differences higher than one notch, a simple probit model was also used to find if it improved on the results previously obtained.

For the rating differences between S\&P and Fitch, when the assigned rating from the first was higher than the latter, we found that, independently of the dataset (full, investment- or speculative-grade), an increase in the budget balance would decrease the rating difference whereas an increase in net debt would increase that same difference. For the speculative-grade ratings, we also found that the existence of a default in the last two or five years would decrease the rating difference between S\&P and Fitch.

When the rating from S\&P is lower than the one from Fitch, we find different behaviours when comparing the results from the investment- and speculative-grade datasets: in the first case, GDP per capita contributes for a smaller rating gap, whereas a default in the last year and inflation contribute for a bigger rating difference. In the latter case, only net debt has an increasing effect on the rating difference; external debt, GDP growth and the existence of a default in the last year, two or ten years reduce the rating difference.

The results of our regressions when Moody's assigns a higher sovereign rating than Fitch are less precise. On the other hand, GDP per capita and inflation respectively influence an investment-grade rating difference in a positive and negative way, external debt and a default in the last year or five years respectively increase and decrease the analogous speculative rating difference. When considering only the investment-grade regressions, our simple probit results also find the budget and structural balances and a default in the last five years as negatively correlated with the rating difference. On the other hand, for the speculative-grade results for Moody's and Fitch positive rating differences, the simple probit approach does not find external debt as significant, when compared with the ordered probit approach for the same dataset. It's also worth noting 
the fact that GDP growth only appears as significant for the ordered probit regressions with the full dataset.

With regard to a rating difference when Moody's assigns a lower rating than Fitch, a higher level of government gross debt leads to a smaller rating difference for both investment- and speculative-grade datasets, with the exception of the simple probit regressions for speculative rating differences, which did not find gross debt significant. Our simple probit regressions with the investment-grade dataset also find net debt to positively affect the rating difference. Inflation is found to negatively influence a rating difference between Moody's and Fitch when the ratings are in the speculative category (irrespective of the chosen probit approach), and a default on the last ten years affect in the same negative way only the rating differences within the ordered probit results.

Looking at the results obtained for the positive rating difference between S\&P and Moody's for the investment-grade dataset, we find that an increase in the level of external debt leads to a smaller rating gap between those two rating agencies. For the same dataset, we find that the simple probit approach also identifies GDP per capita as negatively correlated with the rating difference. For the speculative-grade dataset, both probit methods show net debt as negatively related with the rating difference. It's important to note that for this specific dependent variable, and contrary to what was seen on the regressions of the investment- and speculative- data subsets, only the regressions with the full dataset showed all four default dummy variables as significant and affecting positively the rating gap.

The last dependent variable represents the negative rating difference between $\mathrm{S} \& \mathrm{P}$ and Moody's (that is, a lower rating from S\&P than from Moody's). Both of our probit regressions with the investment-grade dataset show a positive relation between budget balance, gross debt and GDP growth and the rating difference and a negative relation between a default in the last year or two and the same rating difference. The simple probit results also point to the structural balance and a default in the last five years as contributing negatively to the rating difference. When considering the speculative-grade dataset, our results both show that an increase in GDP per capita leads to a smaller rating difference. Both budget balance and gross debt affect the rating difference positively, the former only for the ordered probit regressions and the latter only for the simple probit regressions. External debt also affects negatively the rating difference in our ordered probit regressions. 
There are a few improvements and further questions that may be addressed in the future, in the scope of this work. One could also find a way of specifying which agency is responsible for the rating difference, or as an alternative, discover which factors, in a split rating situation, are correlated with a specific agency upgrade or downgrade.

Another question that can be further assessed is considering different time periods, for instance a period before the 1997 Asian crisis, or periods before and after the 20082009 economic and financial crisis, possibly reflecting differences on how the rating agencies methodologies were applied in those specific periods.

\section{References}

Afonso, A. (2003). "Understanding the determinants of sovereign debt ratings: Evidence for the two leading agencies", Journal of Economics and Finance, 27, 56-74.

Afonso, A., Furceri, D., Gomes, P. (2012). "Sovereign credit ratings and financial markets linkages: Application to European data", Journal of International Money and Finance, 31, 606-638.

Afonso, A., Gomes, P., Rother, P. (2008). "What "Hides" Behind Sovereign Debt Ratings?” in Catalão-Lopes, M., Soares, J., Pina, J. (eds). New Developments in Financial Modelling: Cambridge Scholars Publishing, Chap. 13, pp. 314-343.

Afonso, A., Gomes, P., Rother, P. (2011). "Short- and long-run determinants of sovereign debt credit ratings", International Journal of Finance \& Economics, 16, 1-15.

Al-Sakka, R., ap Gwilym, O. (2010). "Split sovereign ratings and rating migrations in emerging economies", Emerging Markets Review, 11, 79-97.

Amstad, M., Packer, F. (2015). "Sovereign ratings of advanced and emerging economies after the crisis", BIS Quarterly Review December.

Beers, D., Mavalwalla, J. (2016). "Database of Sovereign Defaults, 2016”, Bank of Canada Technical Report, Vol. 101.

Bhatia, A. (2002). "Sovereign Credit Ratings Methodology", International Monetary Fund.

Bissoondoyal-Bheenick, E. (2005). "An analysis of the determinants of sovereign ratings", Global Finance Journal, 15, 251-280.

Brunnermeier, M. (2009). "Deciphering the Liquidity and Credit Crunch 2007-2008", Journal of Economic Perspectives, 23, 77-100.

Cantor, R. (2012). "Sovereign Risk Measurement Methodologies", Presentation at the 2012 Credit Risk Conference, NYU Stern School of Business. 
Cantor, R., Packer, F. (1996). "Determinants and impact of sovereign credit ratings", Economic Policy Review, 2.

Eliasson, A.-C. (2002). "Sovereign credit ratings", Research Notes 02-1, Deutsche Bank Research.

Fitch Ratings (2014) “Definitions of Ratings and Other Forms of Opinion”, Technical report, Fitch Ratings.

Hill, P., Brooks, R., Faff, R. (2010). "Variations in sovereign credit quality assessments across rating agencies", Journal of Banking \& Finance, 34, 1327 - 1343.

Kiff, J., Sylwia, N., Schumacher. L. (2012). "Are Rating Agencies Powerful? An Investigation into the Impact and Accuracy of Sovereign Ratings", Technical report, International Monetary Fund.

Levich, R., Majnoni, G., Reinhart, C. (2012). Ratings, Rating Agencies and the Global Financial System, New York University Salomon Center Series on Financial Markets and Institutions: Springer US.

Livingston, M., Naranjo, A., Zhou, L. (2007). “Asset Opaqueness and Split Bond Ratings", Financial Management, 36, 49-62.

Livingston, M., Naranjo, A., Zhou, L. (2008). "Split bond ratings and rating migration", Journal of Banking \& Finance, 32, 1613-1624.

Moody's Investors Service (2015) “Sovereign Rating Methodology”, Technical report, Moody's Investors Service.

Moody's Investors Service (2016) "Rating Symbols and Definitions", Technical report, Moody's Investors Service.

Mulder, C., Monfort, B. (2000). Using Credit Ratings for Capital Requirements on Lending to Emerging Market Economies: Possible Impact of a New Basel Accord, No. 0-69: International Monetary Fund.

S\&P Global Ratings (2016) "S\&P Global Ratings Definitions", URL: https://www.standardandpoors.com/en_US/web/guest/article/-/view/sourceId/504352, Accessed on 15 September 2016.

Sylla, R. (2002). "An historical primer on the business of credit rating”, in Ratings, rating agencies and the global financial system: Springer, pp. 19-40. 


\section{Appendix - Explanatory variables and country sample}

Table A1 - Summary of the explanatory variables

\begin{tabular}{|c|c|c|c|}
\hline $\begin{array}{l}\text { Predicting } \\
\text { variables }\end{array}$ & Name & $\begin{array}{l}\text { Variable original description and } \\
\text { source }\end{array}$ & Description \\
\hline BudgetBal_NGDP & $\begin{array}{l}\text { Budget } \\
\text { balance }\end{array}$ & $\begin{array}{l}G G R \_N G D P: \text { General government } \\
\text { revenue (percentage of GDP) } \\
G G X \_N G D P: \text { General government total } \\
\text { expenditure (percentage of GDP) } \\
\text { Source: IMF (WEO) }\end{array}$ & $\begin{array}{l}\text { Difference between government } \\
\text { revenues and expenses ( } G G R \_N G D P \\
\left.\text { and } G G X \_N G D P\right) \text {. }\end{array}$ \\
\hline$G G S B \_N P G D P$ & $\begin{array}{l}\text { Structural } \\
\text { balance }\end{array}$ & $\begin{array}{l}\text { General government structural balance } \\
\text { (percentage of potential GDP) } \\
\text { Source: IMF (WEO) }\end{array}$ & \\
\hline$G G X W D G \_N G D P$ & Gross debt & $\begin{array}{l}\text { General government gross debt } \\
\text { (percentage of GDP) }\end{array}$ & \\
\hline$G G X W D N \_N G D P$ & Net debt & $\begin{array}{l}\text { General government net debt } \\
\text { (percentage of GDP) } \\
\text { Source: IMF (WEO) }\end{array}$ & \\
\hline$N G D P \_R P C H$ & $\begin{array}{l}\text { GDP growth } \\
\text { rate }\end{array}$ & $\begin{array}{l}\text { Gross domestic product, constant prices } \\
\text { Source: IMF (WEO) }\end{array}$ & $\begin{array}{l}\text { Annual percentages of constant price } \\
\text { GDP, year-on-year changes. }\end{array}$ \\
\hline$N G D P D P C$ & $\begin{array}{l}\text { GDP per } \\
\text { capita }\end{array}$ & $\begin{array}{l}\text { Gross domestic product per capita, } \\
\text { current prices, expressed in current U.S. } \\
\text { dollars per person. } \\
\text { Source: IMF (WEO) }\end{array}$ & \\
\hline РСРIPCH & Inflation & $\begin{array}{l}\text { Inflation, average consumer prices } \\
\text { Source: IMF (WEO) }\end{array}$ & $\begin{array}{l}\text { Annual percentages of average } \\
\text { consumer prices, year-on-year } \\
\text { changes. }\end{array}$ \\
\hline ExtDebtPercGNI & $\begin{array}{l}\text { External } \\
\text { debt }\end{array}$ & $\begin{array}{l}\text { GNI_USD: Gross National Income } \\
\text { (current US\$) } \\
\text { Source: WB (WDI) } \\
\text { ExtDebtStocksTotalUSD: External debt } \\
\text { stocks, total (DOD, current US\$) } \\
\text { Source: WB (WDI) } \\
\text { GrossExtDebtPosition: 0059_T1_Gross } \\
\text { External Debt Position and External } \\
\text { debt stocks, total (DOD, current US\$) } \\
\text { Source: JE (QEDS) }\end{array}$ & $\begin{array}{l}\text { The WDI dataset had GNI values for } \\
\text { the great majority of countries, so the } \\
\text { GNI values came from the WDI } \\
\text { dataset. } \\
\text { The External Debt values existed on } \\
\text { the WDI dataset, but there were no } \\
\text { values for OECD countries and the } \\
\text { QEDS dataset will replace the WDI } \\
\text { dataset as the canonical source for } \\
\text { external debt. } \\
\text { However, the QEDS dataset only have } \\
\text { values from } 2003 \text { onwards, so we first } \\
\text { used the external debt values from the } \\
\text { WDI } \\
\text { (ExtDebtStocksTotalUSD), and then } \\
\text { we merged the values from the QEDS } \\
\text { dataset } \\
\text { (GrossExtDebtPosition). Since the } \\
\text { QEDS dataset is more recent and uses } \\
\text { an updated methodology, those values } \\
\text { were used when values from both } \\
\text { datasets existed. }\end{array}$ \\
\hline
\end{tabular}




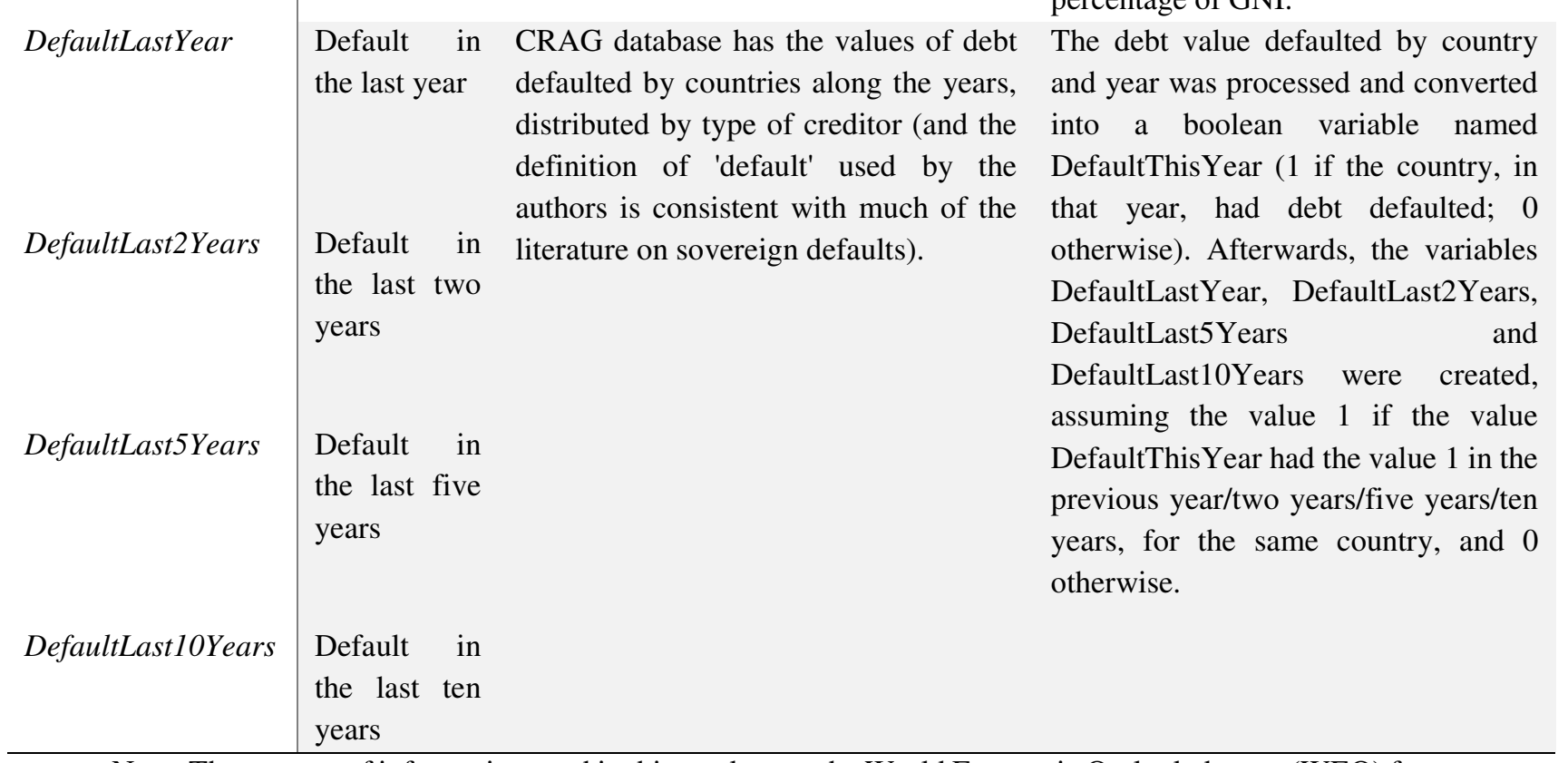

The variable ExtDebtPercGNI was calculated using the combined external debt values (from WDI and QEDS dataset) and the GNI value, and its value equals the external debt value in percentage of GNI.

The debt value defaulted by country and year was processed and converted into a boolean variable named DefaultThisYear ( 1 if the country, in that year, had debt defaulted; 0 otherwise). Afterwards, the variables DefaultLastYear, DefaultLast2Years, DefaultLast5Years and DefaultLast10Years were created, assuming the value 1 if the value DefaultThisYear had the value 1 in the previous year/two years/five years/ten years, for the same country, and 0 otherwise.

Note: The sources of information used in this work were the World Economic Outlook dataset (WEO) from the International Monetary Fund (IMF), the World Development Indicators (WDI) from the World Bank (WB) and the Quarterly External Debt Statistics dataset (QEDS) from the Joint Effort of the WB and the IMF. The variables BudgetBal_NGDP, GGSB_NPGDP, GGXWDG_NGDP, GGXWDN_NGDP, NGDPDPC and ExtDebtPercGNI are expressed in terms of their year-to-year variation.

Countries in the sample: Angola, Albania, United Arab Emirates, Argentina, Armenia, Australia, Austria, Azerbaijan, Belgium, Bulgaria, Bahrain, Bosnia and Herzegovina, Belarus, Belize, Brazil, Barbados, Canada, Switzerland, Chile, China, Côte d'Ivoire, Cameroon, Colombia, Costa Rica, Czech Republic, Germany, Denmark, Dominican Republic, Ecuador, Egypt, Spain, Estonia, Ethiopia, Finland, Fiji, France, Gabon, United Kingdom of Great Britain and Northern Ireland, Georgia, Ghana, Greece, Guatemala, Honduras, Croatia, Hungary, Indonesia, India, Ireland, Iraq, Iceland, Israel, Italy, Jamaica, Jordan, Japan, Kazakhstan, Kenya, Korea (Republic of), Kuwait, Lebanon, Libya, Sri Lanka, Luxembourg, Morocco, Mexico, Mali, Mongolia, Mozambique, Malaysia, Namibia, Nigeria, Netherlands, Norway, New Zealand, Oman, Pakistan, Panama, Peru, Philippines, Papua New Guinea, Poland, Portugal, Paraguay, Qatar, Romania, Russian Federation, Rwanda, Saudi Arabia, Senegal, El Salvador, Serbia, Slovenia, Sweden, Seychelles, Thailand, Trinidad and Tobago, Tunisia, Turkey, Uganda, Ukraine, Uruguay, United States of America, Viet Nam, South Africa, Zambia. 
Table A2 - Countries in our full dataset which in the previous period did not have ratings from two or more of the three main agencies.

\begin{tabular}{|c|c|c|c|c|c|c|c|}
\hline 1980 & 1985 & 1990 & 1995 & 2000 & 2005 & 2010 & 2015 \\
\hline Australia & & Denmark & Argentina & Barbados & Bahrain & Albania & Angola \\
\hline Austria & & Finland & Belgium & Belize & Cameroon & Azerbaijan & Armenia \\
\hline $\begin{array}{l}\text { United } \\
\text { Kingdom }\end{array}$ & & Ireland & Brazil & Bulgaria & $\begin{array}{l}\text { Dominican } \\
\text { Republic }\end{array}$ & Belarus & $\begin{array}{l}\text { Côte } \\
\text { d'Ivoire }\end{array}$ \\
\hline Norway & & Malaysia & Canada & Costa Rica & El Salvador & $\begin{array}{l}\text { Bosnia and } \\
\text { Herzegovina }\end{array}$ & Ethiopia \\
\hline \multirow[t]{25}{*}{ Sweden } & & New Zealand & Chile & Croatia & Ghana & Fiji & Honduras \\
\hline & & Spain & China & Ecuador & Guatemala & Gabon & Iraq \\
\hline & & Thailand & Colombia & Egypt & Mali & Georgia & Namibia \\
\hline & & & Czech Republic & Estonia & Mongolia & Jordan & Paraguay \\
\hline & & & France & India & Mozambique & Kenya & Rwanda \\
\hline & & & Germany & Jamaica & Saudi Arabia & Libya & Senegal \\
\hline & & & Greece & Kazakhstan & Serbia & Nigeria & Zambia \\
\hline & & & Hungary & Korea (Republic of) & Sri Lanka & Seychelles & \\
\hline & & & Iceland & Kuwait & Ukraine & Uganda & \\
\hline & & & Indonesia & Lebanon & Viet Nam & $\begin{array}{l}\text { United Arab } \\
\text { Emirates }\end{array}$ & \\
\hline & & & Israel & Morocco & & & \\
\hline & & & Italy & Oman & & & \\
\hline & & & Japan & Panama & & & \\
\hline & & & Luxembourg & Papua New Guinea & & & \\
\hline & & & Mexico & Peru & & & \\
\hline & & & Netherlands & Qatar & & & \\
\hline & & & Pakistan & Romania & & & \\
\hline & & & Philippines & Russian Federation & & & \\
\hline & & & Poland & Slovenia & & & \\
\hline & & & Portugal & $\begin{array}{l}\text { Trinidad and } \\
\text { Tobago }\end{array}$ & & & \\
\hline & & & South Africa & Tunisia & & & \\
\hline & & & Switzerland & & & & \\
\hline & & & Turkey & & & & \\
\hline & & & United States & & & & \\
\hline & & & Uruguay & & & & \\
\hline
\end{tabular}

Source: rating agencies and own calculations. 